\title{
Pablo Neruda en Inglés
}

En el mismo número del New York Times en que aparece, en la última página, una nota de Nathaniel Tarn sobre "A Nobel for Neruda" (Nov. 7, '71, p. 55) se reproduce en primera plana el manuscrito de The Waste Land con las correcciones y anotaciones de Ezra Pound. Tarn dice que el premio Nobel debió haber sido otorgado a Neruda hace por lo menos diez años. Con lo cual ocurre pensar que tampoco ha habido ningún reconocimiento público de los méritos de Ezra Pound. Es que hay grandes similitudes entre las vidas de los dos más grandes poetas de nuestro tiempo, que es como decir los más grandes poetas del siglo $\mathrm{xx}$. Son los únicos de obra estructurada y monumental. Los dos se hallan encajonados en extremos opuestos, enraizados en opuestos infiernos ideológicos. Los dos mantienen la arrogancia de sus convicciones y un profundo desprecio por la crítica. Los dos se niegan a aceptar amistades efímeras, pero los dos pueden ser, cuando así lo desean, amables con periodistas visitantes. Los dos han sido acusados de ignorancia y plagiarismo, de bigamia y de cómodos exilios. Los dos han estado en la cárcel y han sido perseguidos y atacados como perros rabiosos. Se parecen físicamente, en una hermosura ursina y robusta. $Y$ de ninguno de los dos puede decirse que sea profeta en su propia tierra, a pesar de que ambos han influido en toda la poesía del siglo $\mathrm{xx}, \mathrm{y}$ en todas las latitudes.

Aparte de las posturas políticas, tanto a Neruda como a Pound se les hubiera evitado en los círculos académicos por sus innovaciones atrevidas y el dogmatismo de sus pronunciamientos. Por eso aunque sean reconocidos como poetas entre los poetas, o mejor dicho, poetas para poetas, no se encuentra hasta ahora ninguna autoridad crítica que se dedique firmemente al uno o al otro. $\mathrm{Ni}$ hay autoridades sobre Pound, ni hay autoridades sobre Neruda. En cuanto a Neruda pudiera aducirse que hay cierta riqueza relativa en inglés, pero es más bien ocasional y a veces oportunista. La frialdad de la actitud de académicos y profesores 
puede medirse por la escasez de tesis doctorales que toman a Neruda co. mo tema de investigación. Hay, además, otros indicios como por ejemplo los honores académicos. El mayor galardón de esta calidad sería un doctorado honoris causa. Pablo Neruda recibió el doctorado de Oxford, en 1965, el. primer hispanoamericano en recibir la honrosa distinción. Como se notará en el curso de este trabajo, la aceptación de Neruda en Inglaterra ha sido un poco más informada que en los EEUU.

Los doctorados de honor en los EEUU se dan por muchas y muy diversas causas, casi todas de mutua conveniencia. Neruda, claro, no ha recibido ninguno. Hay, además, asociaciones de vieja raigambre académica que mantienen listas de honor. Una es la "Modern Language Association of America" y orta la "American Association of Teachers of Spanish and Portuguese", MLA y AATSP, respectivamente. MLA comprende a los especialistas en idiomas extranjeros y a los profesores de inglés. Para marcar la separación entre investigadores y artistas creadores esta vieja organización, de proclividades críticas a la manera teutónica, honra con dos formas diferentes de asociación de honor, una para los artistas creadores, otra para los eruditos. A la primera categoría, de bono. rary fellow, Neruda fue elegido en 1961, el mismo año que también honraron a Borges, a Dürrenmatt y a los norteamericanos Robert Lowell y Marianne Moore; Malraux y Seferis habian entrado un año antes. Y después de Neruda recibieron a Beckett, a Ionesco, Lévi-Strauss, Octavio Paz, Sartre era miembro desde 1959. Jorge Guillén era socio de honor desde 1938.

Los profesores de español y portugués se mostraron un tanto más quisquillosos. AAT'Sp no reconoció a Neruda hasta 1967, año en el que entró con un nutrido grupo: Alberti, Jorge Amado, Asturias, Carrera Andrade, Delibes, Guillén (Jorge, claro, no Nicolás) Icaza, Rojas. Borges había sido escogido en 1965. Para admirar el delicado tentempié de la asociación basta con notar que de sus 29 miembros honorarios, 13 son españoles, 13 de la América de habla española y 3 del Brasil.

Un examen somero de las listas de disertaciones doctorales no es mucho más ilustrativo. Los datos de AATSP parecen ser incompletos, se adivinan omisiones y se pueden notar nombres repetidos y contados más de una vez. Los títulos cambian o se repiten. De 1935 a 1953 (Hispania, v. 37, 185) se notan tesis doctorales sobre Martí, Mistral, Nervo y una sobre Juan de Dios Peza, peto no Neruda. Entre 1949 y 1963 se otorgaton 644 doctorados y sus tecipientes escribieron sobre Borges, Gorostiza, Ballagas y muchos otros escritores contemporáneos, pero nadie sobre Neruda. Este no aparece hasta 1968. De un total de 
136 disertaciones solamente una, la de Eliana Suárez Rivero, trata de Ne. ruda bajo el título "El gran amor de Pablo Neruda", publicada en Ma. drid (Ediciones Plaza Mayor, 1971), con el título El gran amor de Pablo Nerud'a: Estudio crítico de su poesía. En 1970 se anunció una tesis doc. toral, en preparación, por P. C. Highman, "Alturas de Macchu Picchu y la obra de Neruda". Después, en el congreso anual de la "Modern Language Association" celebrado en Chicago en diciembre de $197^{\circ}$, se aceptó un trabajo de Keith A. McDuffie sobre "Vallejo y Neruda: dos poetas frente al surrealismo". Pero con la nueva ola y los nuevos vientos que soplan en la nación norteamericana - donde se considera que hay una población de habla española de $16.205,150$ personas- se puede no. tar la aparición de trabajos de más profunda envergadura, y en 1970 Luis González Cruz, en la Universidad de Pittsburgh, presentó su tesis doctoral, con el profesor Alfredo Roggiano, sobre "Integration of the Poetic Vision in Pablo Neruda's Memorial de Isla Negra".

\section{NERUDA EN REVISTAS ACADÉMICAS.}

Para medir la influencia de un autor deben examinarse, desde luego, las revistas académicas, $y$ las de interés general, las antologías, las referencias y citas en libros y sobre todo las traducciones. El nombre completo de revistas y periódicos se dará, aquí, solamente en la primera mención y después se usarán las iniciales. Se han de citar las referencias tomadas de publicaciones inglesas en su versión española, y a no ser que se indique lo contrario, la traducción es de la autora.

La publicación universitaria en un país de habla inglesa que propiamente descubrió a Neruda y se ocupó de él en un trabajo de importancia académica fue la Revista Hispánica Moderna (RHM). Aunque impresa en Cuba y dirigida por el español Federico de Onís, estaba subvencionada por Columbia University de la ciudad de Nueva York, para la circulación en los EEUU, donde alcanzó gran influencia entre los profesores de enseñanza secundaria a cuyas actividades dedicaba secciones especiales. En octubre de 1936 publicó el muy pocas veces mencionado pero muy importante trabajo de Concha Meléndez "Pablo Neruda en su extremo imperio" (V. III, p. 1.32). Todo lo que se ha dicho de la poesía de Neruda hasta hoy parte de este estudio, en el que se inspiró el tan famoso libro de Amado Alonso. Es una evaluación, muy moderna y muy atinada, de la técnica de Neruda. En el mismo número de la revista, en la sección escolar, se transcriben "Farewell", "Poema número 15", "Unidad" y 
"Entrada a la madera". En el mismo año se of reció una lectura de poemas en el Ateneo de Puerto Rico que reseña la misma profesora (julio, 1937, 338). Cuenta que los poemas de Neruda alcanzaron gran éxito y que "Todo ello se hizo con sencillez y sobriedad que el genio esquivo de Neruda aplaudiría", observación clarividente y profética, genio esquivo. Con el trabajo de Concha Meléndez aparece la bibliografía de Neruda preparada por Sidonia C. Rosenbaum.

Doña Concha inicia en RHM una tradición de estudios sólidos. La evaluación de Neruda es constante y es la única revista en que se advierte un interés persistente en la obra del poeta chileno. En 1939 publica artículos de Andrés Iduarte y de Amado Alonso. En 1947 Iduarte habla de la Tercera residencia; en 1949 Rabassa sobre Poemas de amor; Florit sobre las Poesias completas en 1954. Carlos Hamilton estudia el "Itinerario de Pablo Neruda" en 1956, año en que Florit escribe "Un nuevo acento en Pablo Neruda". De Monguió, en 1957, "El concepto de la poesía en algunos poetas hispanoamericanos representativos" se abre con una cita de Neruda; se trata de una conferencia of recida en la Universidad de Cinncinati, Ohio, en octubre de 1955. En 1957 Folgequist reseña las Nuevas oddas elementales; en 1959 Luis García Abrines escribe "La forma de la última poesía de Pablo Neruda". En 1962 John A. Coleman está a cargo de reseñar Cien sonetos de amor; John H. R. Polt había publicado "Elementos gongorinos" en "El gran océano", un año antes. En 1963 Mireya Jaimes-Freyre reseña una Antología poética compilada por Pablo Luis Avila, publicada en Turín. La misma autora menciona a Neruda en una reseña de la Literatura bispanoamericana de Valbuena Briones, de quien dice "Parece no comprender Veinte poemas..." (317); También en este año Jaimes-Freyre había escrito sobre la traducción de Lozano The Elementary Odes of Pablo Neruda sin estar de acuerdo con el título, pero calificando la traducción y el prefacio de Alegría de excelentes. A renglón seguido José $\mathrm{O}$. Jiménez reseña Cantos ceremaniales. Su "Inútil fuera señalarlo como un reparo..." (p. 178) ejemplifica la tónica de mucho de lo que se ha escrito sobre Neruda y los errados derroteros -según los críticos- de su poesía. Un artículo de importancia "Residencia en la tierra, algunas correcciones", por Al. fredo Lozada, data de 1964. Fue leído en Memphis, Tenn., en noviembre de 1963; el autor agradece la beca del "Social Science Research Council" que le permitió viajar a Chile para confirmar sus datos. Es un análisis muy documentado de Residencia que trata de refutar juicios de Amado Alonso. Se publicó otro trabajado de Lozada, "Neruda y Schopenhauer" en 1966 (p. 217). Ese mismo año Folgequist habla de 
Memarial de Isla Negra y se reseñó también el libro de J. Alazraki sobre Neruda.

Al parecer la primera mención de Neruda en inglés se debe a uno de los primeros hispanistas, Willis Knapp Jones, quien en 1929 publicó una nota en Books Abroad sobre Crepusculario. A pesar de tan distinguido preludio BA no cuenta en sus páginas con mucho Neruda, quizá porque responde más a intereses internos de departamentos universitatios que al natural empuje de las corrientes literarias. Contiene los siguientes comentarios: Maurice Halperin en 1941, Concha Meléndez en 1944, Manuel H. Guerra en 1956, Homero Castillo en 1962 y 1963, T. B. Barclay en 1968, en 1971 Jaime Alazraki y John Deredita.

Una revista influyente es PMLA, que publica la antes citada "Modern Language Association". Se distingue por su inclinación hacia la minuciosidad abstrusa y artículos ricos en notas, citas, anotaciones, cotejos, etc. y escaso texto original - y cosas peores ha dicho de ella el conocido crítico Edmund Wilson. Entre 1940 y 1950 solamente reconoció a Gabriela Mistral. Al fin, en 1964, publicó un valioso estudio de Alfredo Lozada, "Estilo y poesía de Pablo Neruda" (Dic. 64, p. 649), magnífico acierto de literatura comparada. La sección de literatura comparada de MLA publica también Comparative Literature con la Universidad de Oregon, aún más atrasada de noticias que PMLA. No menciona a Neruda.

Jornal of Interamerican Studies, (abril, 1966) publicó un trabajo de Lozada con una interpretación socioeconómica de Residencia en la tierra. Romance Notes (XI, 1970) trae el novedoso trabajo de Keith Ellis "Poema Veinte, a structural approach". En Romanic Review, (XLVII, 1956, p. 134) se publicó una reseña del libro de Alegría Walt Whitman en Hispano América en la que se habla de Neruda. En Inglaterra, Bulletin of Hispanic Studies, de Liverpool, en 1949 un artículo de E. Allison Peers (p. 117) sobre la edición Cruz del Sur de la Obra poética. Aunque no $\tan$ hostil - se trata desde luego de un artículo firmado- emplea los mismos adjetivos que Times Literary Supplement de Londres ha de esgrimir en 1954. En 1968, en una nota bibliográfica, habla de Neruda para decirnos que cierto libro ha omitido a Neruda y a Guillén (V. 45, p. 77). La Revista Iberodmericana tiene un carácter internacional y cosmopolita que la hace diferente a las otras publicaciones de Norteamérica más cerradas en ámbito, círculo y colaboradores. Por lo tanto Neruda está presente en muchos aspectos, como por ejemplo en el artículo de James K. MacDonald (N. 56, 1963, p. 333), quien nos descubre que Neruda publicó dos artículos en la revista mexicana Taller. O una mención de que Neruda estấ en París (V. 22, p. 44). También trae los estudios de 
Ricardo Navas-Ruiz, "Neruda y Guillén, un caso de relaciones literarias" (N. 60, 1065) y de Luis F. González Cruz "Vida y muerte en Pablo Neruda: dos poemas del Canto General" (No. 70, Marzo 1970). Aparece una reseña del libro de Margarita Aguirre firmada por Lozada (N. 63, p. 167, 1967), y Julio Durán Cerda, de la Universidad de Chile, menciona a Neruda en una reseña de La literdature cbilena en los EEUU, de Homero Castillo (1964, p. 335).

Intellectual Digest se ha ocupado dos veces de Neruda. Su segundo reportaje es bilingüe, firmado por Alden Whitman (marzo, 1972, p. 49). Los idiomas que emplea son el inglés y el francés. Se trata de una entrevista, preguntas en inglés, respuestas de Neruda en Francés, idioma que emplea "with a fine sense of diplomacy". Teniendo en cuenta que Neruda dijo en esta entrevista que Angela Davis no podía andar libre por las calles pero sí los culpables de las crueldades en Vietnam no queda duda de que el "fine sense of diplomacy" se aplica más a la revista norteamericana que al poeta chileno. La entrevista se titula "Walt Whitman, votre ancêtre, ets un bon ami à moi..."

Otra revista de interés para los hispanistas es Hispania, publicación oficial de AATSP. Las páginas de Hispania no revelan ninguna inclinación especial a informar a sus socios de las vicisitudes de la vida de Neruda o de comentar su copiosa producción. En sus buenos tiempos Hispania era pro-península, ahora está orientada hacia la literatura mexicana, que por razones de importancia geográfica es la que predomina en el país, Esta revista es simpática, sin la formalidad pomposa de PMLA, y protege con solicitud maternal a los talentos jóvenes de Norteamérica. El índice de 1948 a 1967 no muestra ningún Neruda. Después se encuentran referencias sueltas. Merece citarse el breve trabajo de John M. Tolman "Death and alien environment in Pablo Neruda's Residencia..." (marzo, 1968, p. 79). en 1969 R. G. Mead reprodujo el artículo de M. B. Brown del NYT (New York Times) del 8 de abril de 1969, del que hablaremos más adelante. En 1970 Neruda es Nerurda (sic) en el indice; Betanzos, en la p. 544 lo menciona en relación con la antología de Tri-Quarterly. Sabemos que ha sido traducido al polaco, y se lista, sin comentario, la aparición de $A$ New Decade, la traducción de Bellit. En 1971, p. 187, Seymour Menton habla de la llegada a Caracas de Pablo Neruda para asistir al III Congreso de la Comunidad Latinoamericana de Escritores. Pero no menciona que, a juzgar por el séquito que lo seguía continuamente, Neruda tiene más simpatía en Venezuela que J. L. Borges. Y es lástima que no haya contado cómo los dos gigantes, en la mesa presidencial, juntaron sus cabezas para conversar empujando 
hacia atrás al paciente Mejía Sánchez, sentado entre los dos. También en una nota de Yulan Washburn se dice que Neruda ha sido nombrado embajador en Francia y se menciona un periódico de Buenos Aires en el cual se afirmaba que "el Neruda político no tiene mucho que hacer, ahora, en Chile."

\section{REVISTAS Y PERIÓDICOS DE CARÁCTER GENERAL.}

Inglaterra y los EEUU, civilizaciones basadas en papel y en comunicaciones públicas, tienen innumerables revistas, elegantes, profesionales, sofisticadas, o para minorias, o para adolescentes, o para tantos, o para los avisados. Sobresalen, sin embargo, dos publicaciones semanales de carácter bibliográfico. En los EEUU tenemos el New York Times Book Review que se publica todos los domingos. La otra es el London Times Literary Supplement, más informada y más especializada que la anterior. La revista inglesa, - TLS de ahora en adelante-, apenas conocía antes de la segunda guerra mundial la existencia de la América española y ni siquiera sabía cómo referirse a ella en el índice. En 1944 (p. 91) hizo un esfuerzo patético para descubrirla y reseñó libros conocidos y libros ya para siempre olvidados, pero nada de Neruda. Sin embargo, el 24 de agosto de 1951, bajo el título "En la América Latina" hay un elegante y mesurado párrafo sobre Neruda. Este mismo artículo, más completo, con el título "Tradición e independencia en las letras hispanoamericanas", apareció en Marcba, Montevideo, en diciembre de 1951, revelándose así el nombre del autor, Emir Rodríguez Monegal. Estos artículos no aparecen en la bibliografía sobre Neruda recogidos en las OC. Pero no le llevó mucho tiempo al TLs para refugiarse en su previa ignorancia. El 12 de marzo de 1954 las mismas páginas de solidez cultural británica se refieren a un grupo de recién llegados: Herrera y Reissig, Vallejo, Alberti, y muy especialmente Neruda, con su edición de Canto géneral (sic), de la Imprenta Juárez, México, 1950. (De esta edición dice Hernán Loyola, OC, II, p. 1360, que se trata de una tirada clandestina del Partido Comunista de Chile). A través del artículo se mantiene la ortografía géneral:

Partiendo del aislamiento de Molinari, pero con mucha menos pureza del lenguaje, y sin alzarse hasta la ira de Vallejo aunque también sin su descuidada actitud hacia su arte, Pablo Neruda ha intentado en su Canto géneral escribir una consciente poesía americana, que pueda lograr, no sólo para su Chile natal, sino para 
todo el continente, lo que hizo Whitman por los EEUU. El objetivo de Neruda es despertar la conciencia suramericana y borrar el sentido indio de resignación contra el cual también luchó Vallejo. Loa con sus himnos, los ríos y los llanos del sur, pero no como símbolos de un cielo vacío que espera ser poblado por ángeles, sino por sus tiquezas en ganado, cereales, minerales, fuentes de energía que podrán convertirse en ingresos para sus moradores. Trata de sustituir los viejos dioses con una raza de héroes y de mártires... La falta de equilibrio entre el propósito de describir todo un continente y la burda parcialidad de sus pronunciamientos arruina la integridad del largo poema. Página tras páginas de declamaciones airadas ensordecen al lector sin dejar más rastro que una parrafada periodística. El Canto es, en gran parte, vacio e ininteligible. Pero en sus mejores pasajes logra dar una visión amplia del país y de su pasado no europeo. Neruda, antes de hacerse comunista, era un poeta de imágenes surrealistas originales y esta imaginería, aunque ahora menos violenta, le sirve para describir algunos aspectos del paisaje chileno... Todavía se notan trazas del poeta de Residencia en la tierra en la descripción del desembarco de Ercilla en Chile... Este volumen, cuando no está lleno de repeticiones retóricas, parece estar lleno de denunciaciones políticas... Quizá sea, aún dentro de su crudeza, el poema de la América del Sur de mediados de este siglo. Quizá. . su insistencia, su primitivismo y su monotonía, sus ataques viriles, su carencia de tono metafórico... sea todo lo que se puede esperar de las obras primitivas de una literatura recién nacida...

El artículo es anónimo, como lo son todos los que se publican en TLs, que en 1956 menciona a Neruda en el editorial (p. 569), en referencia a la Bienal de Poesía que se celebró en Bélgica. Allí, a través de discusiones, se llegó a la conclusión de que "las proclamaciones de carácter socialista y la búsqueda del bien público (como en muchos poemas de Neruda y Eluard) pueden coexistir con un lenguaje delicado y artificioso". Se informa que la tarea de los jueces que seleccionaron a Ungaretti, fue muy ardua, puesto que tenían ante ellos los nombres de "W. H. Auden, Paul Celan, Pierre Emmanuel y Pablo Neruda"...

Dos años después, en enero del 58, dedica a Neruda una páigina entera, con citas en español, de las Obras completas. Dice que la poesía de los Veinte poemas es "brutalmente y extáticamente física". Que en la poesía de guerra es inferior a Alberti y a Vallejo. Que España en el co- 
razón es "un libro chillón y desordenado". Concede que hay "una docena, - quizás dos, de grandes poemas en el Canto general, los que tratan de la naturaleza." Teniendo en cuenta la estudiada reserva británica, lo siguiente constituye un elogio profundo y sentido: "Neruda es uno de los grandes poetas, en realidad el único poeta contemporáneo para quien el mundo físico, desde los minerales hasta el hombre, desde su Chile natal hasta la China comunista, son temas de inspiración". Pero todavía por entonces la actitud del supplement era ambivalente, oscilante entre admiración y desprecio. En octubre de 1959 un artículo que pudiera tomarse como el canto del cisne de una añeja generación de críticos, enarbola el estandarte de la influencia española. Habla de la "exuberancia tropical de Darío", y de "las imitaciones de Juan Ramón que abundan desde México a Buenos Aires" y:

$Y$ finalmente el chileno Pablo Neruda ha influido en todos los poetas de una generación del mundo de habla española, primero con los versos libres surrealistas de las Residencias, después con el apasionado contenido social del Canto general y al fin con el fácil y familiar estilo de las Odas elementales. De España, por otra parte, en los años de la predominancia de Neruda, llegaron los poetas emigrados, Rafael Alberti, Luis Cernuda y Emilio Prados, que con su presencia y también con su técnica, estimularon el cultivo de la poesía en América" (p. 596)

Con lo cual se comprueba que también los británicos pueden producir parrafadas ilógicas. El artículo es curioso, ningún crítico medianamente serio se hubiera atrevido a publicarlo bajo su propio nombre y solamente un dómine necio podría inventar las tonterías con que analiza Estravagario y el Tercer libro de las odas. Cree que la fuerza poética de Neruda, al contrario de la de Guillén, "parece debilitarse". Comparar, como en este caso, un poeta de obra cerebral y mínima, con un poeta de producción vasta y evolutiva es desde Inego, irrelevant. Sigue: "las odas de Neruda se deterioran hasta convertirse en cliché o bufonada o en las dos cosas a la vez. . Neruda ha sido siempre un poeta de ideas superficiales" Estravagario es un libro monótono en el que muestra "todos los aspectos de su mal gusto". En contradicción a lo publicado años atráp admite que todavía es Neruda "el gran poeta del Canto general".

En julio de 1961 se habla de la desoladora pobreza de toda la poesía europea, sin mencionar a América. En octubre trae informaciones sobre premios y traducciones, sobre PEN. Pero los dioses vengativos de los 
araucanos andaban escondidos entre las nieblas inglesas y deslizaron en la revista un curioso poema de Hans Magnus Enzersberger titulado "Honor al apio" (p. 739). El sabor nerudiano es patente; ". . alabemos a la pacífica leche/glorifiquemos al buho, que sabe su nombre/ y no se acorbada, honor/ a la sal y a la ballena ilustrísima, y al bondadoso apio/ al que bendicen las cocineras/ y que se muere en su plato..." (De Enzenberger hay una edición inglesa en la colección Penguin Modern European Poets. Uno de los cotraductores es Jerome Rothenberg, también traductor de Neruda).

Para 1965 acepta la presencia latinoamericana y publica el artículo "Southern Crosses" sobre las novelas (p. 867) en un número dedicado a libros extranjeros. Para entonces la influencia hispanoamericana es tan penetrante que un artículo dedicado a la poesía norteamericana se titula "Songs among the ruins", muy reminiscente de Octavio Paz. En este artículo se habla de Robert Bly, uno de los más.fieles admiradores de Neruda, sin nombrar a Neruda, pero contra Neruda vuelven a la carga años después, 1967 (p. 220) para criticar acerbamente la traducción de Maccbu Piccbu debida a Nathaniel Tarn. El título es "Un Neruda herrumbroso" (p. 220). De la traducción dice que ni es exacta ni está escrita en buen inglés. Neruda se caracteriza por el "erotismo mórbido" de la primera etapa y el "discutible humanismo humanitario" que lo caracteriza a partir de Maccbu Piccbu. Neruda "funde expresiones chilenas con un vocabulario e imágenes de la poesía española del Siglo de Oro". Los críticos que se han pasado cuatro siglos exhortando a los hispanoamericanos a agradecer el idioma que les ha dado España, ahora protestan porque ese mismo idioma se emplea para escribir buenos poemas. En este año 1967 Neruda estuvo en Londres. TLS cuenta que el poeta Ted Hughes (el que estuvo casado con la desaparecida Sylvia Plath), logtó convencer a Neruda y a Paz (como también a Yves Bonnefoy y a Ungaretti) a leer sus poemas en el Festival Internacional de Poesía. El reportaje del festival describe un Neruda muy circunspecto, en toda apariencia un hombre de negocios, que escuchó imperturbable las terribles lecturas que de sus poemas hizo un actor profesional, y después, como en protesta, "hizo temblat el salón con la magia de sus encantamientos" (p. 648).

En 1968 una página entera dedicada a poemas extranjeros incluye "La memoria" en una traducción de Alistair Reid. Esta misma composición aparece incluída en $A$ New Decale, pero en una alambicada versión de Ben Belitt que sirve para mostrar las diferencias en técnica entre los traductores norteamericanos y los ingleses. Las primeras líneas 
de Neruda dicen "Tengo que acordarme de todo, escoger las briznas, los hilos." En la traducción de Reid se conservan todos los elementos del ariginal y se reproducen, además, en un lenguaje poético. En la norteamericana las briznas se han transformado en el viento que pasa. Otros poetas incluídos en este número son Anna Akhmatova, Montale, Bertolt Brecht, Enzensberger, Fortini, Ungaretti y Borges. En noviembre de ese mismo año apareció el conocido número dedicado a la América española, con artículos de Paz, Vargas Llosa y Emir Rodríguez Monegal. Monegal dice que hay dos poesías, una anterior $y$ otra posterior a Neruda: "la poesía post-nerudiana busca una dimensión más introspectiva". Paz habla de Neruda y también de Pound. Dice de Residencia en la tierra: "La tierra o el país que describe Neruda no pertenece a la his. toria. No es Chile ni la América precolombina, sino más bien un mito geológico... su contemporaneidad está más allá de la historia, donde las fechas han sido abolidas... Neruda no es cristiano y no se siente culpable de no serlo. ..". En el mismo número una reseña de los Veinte poemas, en la traducción de Bly-Wright, se afirma que la poesía de Neruda es "vasta, barroca" y se le compara no con Whitman, sino con Milton.

En 1969 un crítico que se refiere a César Vallejo dice que su “influencia en el mundo de habla española puede compararse solamente con la de Pablo Neruda" (p. 1098). En 1970 se reseña el libro de Jean Franco y se habla de Neruda con conocimiento (p. 4). Sobre este libro de Franco debe leerse un excelente trabajo en Revista Iberoamericana, 66, diciembre 1968, donde el autor, Alfredo A. Roggiano, of rece información adicional sobre "lo que se ha hecho en Gran Bretaña en materia de estudios latinoamericanos". El mismo autor comenta dicha obra, en inglés en la Hispanic American Historical Review, el mismo nño 1968, Franco y Neruda se unen de nuevo en TLs en referecia a The Penguin Companion to Literature, obra que acaba de aparecer después de nueve años en preparación (Julio 7, 1972, p. 780).

El mejor, y quizás el más importante artículo que el TLs ha publicado sobre la literatura en español, es del 16 de abril de 1970, cuando, en primera plana, trae un delicado estudio sobre Neruda, con reseñas de sus Obras completas y del pequeño volumen Aím. También reseña: de Loyola Ser y morir en Pablo Neruda; de Alazraki, Poesía y poética de Pablo Nenuda; de Emir Rodríguez Monegal, El viajero inmóvil; y de Margarita Aguirte, Las vidas de Pablo Neruda. Este trabajo, aunque a veces contradictorio, merece especial atención porque revela la mente brillante $\epsilon$ informada de un genuino investigador que no puede escapar 
totalmente a la larga tradición británica de examinar el mundo cultural desde las cumbres de su propia superiotidad ética. De Veinte poemas de amor dice, entre otras cosas, que sustituyó a Bécquer entre los enamorados "gracias a su penettante análisis de las emociones, el inquietante sabor de su eroticismo ostensible...". Quizá en Inglaterra todavía no se hayan enterado, pero cuando Neruda empezó a escribir ya hacía muchos años que Bécquer había dejado de inspirar a los enamorados; la mención de Amado Nervo hubiera sido un poco más acertada. En cuanto a esa delirante obsesión inglesa con el "eroticismo nerudiano" es un poco ridícula si se tienen en cuenta versos al estilo de "nymphs and satyrs/copulate in the foam" o "...The young/in one another's arms" de su propio Yeats, o la directa pornografía de James Joyce en "The Holy Office" y en cuanto a otros poetas, propiamente ingleses, basta con recordar el soneto XX de Shakespeare.

El articulista cree que Residencia en la tierra es uno de los mejores ejemplos del surrealismo en el idioma español. Que España en el corazón es acre y desigual, que Canto general ha sido aceptado como el canto épico del hombre latinoamericano. También dice que apenas se le conocía en Inglaterra antes de su visita a Oxford en 1965 para recibir el primer doctorado bonoris causa en literatura latinoamericana. Los periódicos descubrieron entonces su existencia, y aún más, después de tomar parte en Poesía 67:

entonces empezó a estar de moda aparentar que uno lo había conocido desde muchos años atrás. Su impresión sobre la audiencia fue notable: su reserva y su porte casi majestuoso, sus párpados cargados, retirado, impasible, casi soñoliento, al parecer más allá de todo diảlogo hasta que empezaba a hablar... empezó sorprendiendo a sus oyentes, pero terminó dominándoles por completo. Desde entonces sus poemas han empezado, poco a poco, a traducirse al inglés. No queda duda de que Neruda también ha "arribado" en Inglaterra.

La poesía de Neruda siempre ha sido desigual, su peor defecto es su incapacidad para evaluar su propia obra y descartar las piezas de menos valor... A pesar de todo en los últimos veinte años ha escrito algunos de sus mejores poemas.

Las Odas. . hicieron surgir el sentido del humor de Neruda. La gracia quedamente sutil de muchas de las odas -que llega a su máximo en el inclasificable Estravagario - es una curiosa mezcla, nada española, de ingenio moderado, a menudo se burla de sí 
mismo: algo netamente chileno pero al mismo tiempo tan inglés que un crítico reciente acuñó la palabra güimsicalidad (de whim. sicality) para denominarla... Este humor astringente es nuevo en la poesía española, y extraordinariamente seductor. Fuera de nuestro país y de Chile, sin embargo, las Oddas han sido recibidas con solemnidad, mientras que Estrawagario -en muchos aspectos el más simpático de los libros de Neruda- ha recibido atención solamente porque contiene algunas de sus favoritas composiciones de "recital".

Neruda sigue siendo la principal figura del Partido Comunista de Chile, hace poco que fue pre-candidato a las elecciones presidenciales de 1971. Pero su poesía, desde Las uvas y el viento, ha ido más allá de la política, y lo que su dedicación ha sido para él probablemente es más una cuestión de sentimientos que un programa ideológico. Su conversión al comunismo fue en sí misma una lección espiritual, como se demuestra en "A mi partido" (el penúltimo poema del Canto general).

El artículo no se limita a estudiar las obras de Neruda una por una, sino también los cambios introducidos en la edición de 1968, la biblio. grafía de Alonso M. Escudero y la de Hernán Loyola, y también su libro sobre Neruda, del que dice que su mejor contribución es el estudio del desarrollo de las ideas políticas del poeta. Opina que el libro de Alazraki se basa demasiado en las teorías Wellek-Warren, que divide y subdivide a Neruda dando a cada subdivisión su apropiada etiqueta; y añade: "Y de acuerdo con esto se muestra como la poesía de Neruda corresponde a las etiquetas, sugiriendo implícitamente que cambió de acuerdo a la moda, cuando de hecho a menudo la hizo cambiar". Del libro de Monegal dice que es penetrante, que la primera parte es la mejor, que la discusión de la poesía a veces no es adecuada por demasiado comprimida, añadiendo que es "el mejor libro que se ha escrito sobre Neruda". Este trabajo, de autor anónimo pero más o menos adivinable - Monegal, por ejemplo, cree reconocer al autor- termina con la aserción de que Neruda es un poeta universal precisamente por ser un poeta profundamente chileno. "Como el cielo en "la gran lluvia del sur" Neruda creció hacia abajo hasta que tocó las raíces, y estas raíces resultaron ser sus mismas raíces. Su comprensión de la índole de este lazo jamás fue más simplemente o más sentidamente expresada que en Aín, su última obra, que es uno de sus más nobles poemas". Se refiere el autor al hermoso verso crece el cielo bacia abajo tocando las raices (Soneto LXVII, OC, II, p. 324) y cierra 
así con broche de oro el tratamiento del poeta, tan distinto al artículo piadosamente olvidado de 1954.

TLS se ocupa otra vez de Neruda el 25 de septiembre de 1970 (p. 1087) con una reseña que trata de la traducción que hizo Merwin de los Veinte poemas de amor y de la antología que Tarn preparó y que publicó en Londres (Cape, 1970; la edición norteamericana aparecerá dos años después). Esta reseña es interesante porque habla de otras traducciones de Neruda menos conocidas y que ni siquiera aparecen en la lista incluidas en las OC. (La lista británica en las OC comienza con Nancy Cunard; para ésta véase The Last Great Cause de Stanley Weintraub, N. Y. 1968). Afirma que en 1955 Patrick Bowles hizo una versión de los Veinte poemas de amor (Merlin: The Paris Quarterly, V. 4/2), que fue punto de partida para The Man Who Told His Love (Scorpion Press, 1958). Esto muestra que ha habido en Inglaterra un movimiento nerudiano que empezó por traducciones directas y llegó a producir composiciones confesadamente inspiradas en Neruda. Cree que Logue es uno de los mejores traductores de Neruda y no se pasa por alto la oportunidad de señalar las equivocaciones que comete Merwin. Como contrapeso cita como excelente ejemplo de versión poética el pasaje en que Merwin se ha equivocado al traducir el verbo doblar por tañer, es decir que tanto traductor como comentarista andaban un poco por las nubes. Del segundo libro, que es también el último que ha sido publicado en los EEUU, opina que las traducciones de Tarn y Merwin son buenas, que las de Kerrigan son sosas y que Alistair Reid logra captar el humor travieso de Neruda. Habla del humor de Neruda: una "gracia áspera" que, según el crítico, no se encuentra en lo español. Esto suena a cosa afirmada anteriormente en el mismo periódico. (¿Por qué hay que recalcar que el sentido del humor de Neruda no es español, si lo cierto es que Neruda no es español?) También dice, con razón, que hay muchas equivocaciones en este volumen. Las equivocaciones de vocabulario son tan comunes en las traducciones de Neruda que han pasado a ser una característica en masa. En esto Neruda es tan responsable como sus traductores, puesto que no insiste en revisar, o hacer revisar por editores bilingües, las producciones de sus admiradores de habla inglesa. Una referencia a Neruda, más reciente, se encuentra en la reseña del libro de Saul Yurkievich, Fundador de la nueva poesia latinoumericana (ag. 27, 1971).

Para terminar con el importante periódico londinense vamos a volver atrás veinticinco años, cuando publicó una reseña de la traducción de Angel Flores. El 25 de octubre de 1947. (p. 550) afirmaba que: 
La frecuente recurrencia de ciertas palabras y de ciertos grupos de palabras en la obra primigenia de este poeta chileno suena a desolada música familiar, es la melodía repetitiva de la época entre dos guerras, el grito de un espíritu atormentado, desconcertado por las complejidades de una civilización mecanizada... Entre toda esta decoración simbolista se pasea el fantasma de Eliot, quizá un poco de Rimbaud y Chirico, y ciettamente mucho del ubicuo y pernicioso Freud... Pero aún en esta temprana y derivativa fase, entre una confusión de imágenes pasadas de moda, sobresalen las características más agradables de la poesía de Neruda. Pueden definirse como una voluptuosidad mística, típicamente española, y el delicado don de identificarse con todas las cosas vivas. . . a veces sugiriendo sutiles afinidades químicas, otras una compenetración espiritual.

En general todas las reseñas británicas, especialmente las del TLS, son evasivas y ambiguas, los ataques caen con una ironía fina y devastadora. A pesar de esto no se notan ciertas repeticiones de adjetivos y posiciones críticas que sugieren un mismo autor a través de ciertos años. También es evidente que hay dos tópicos en presencia constante: primero, la composición entre lo que hace Neruda, poeta de Chile (país que está muy lejos, geográficamente y en otras cosas, de España) y las características de la literatura española peninsular. La otra reside en los melindres de castidad ofendida por el erotismo de Neruda y este erotismo, francamente, no se parece en nada a lo que en este siglo se llama erotismo. Básicamente dos generaciones de críticos británicos, aunque dispuestos a aceptar el arte de Neruda en mayor o menor grado, todavía están atados por los mismos prejuicios.

\section{El New York Times Book Review}

Lo que es el ths para el mundo internacional lo es el NYTBR para el consumo interno de los EEUU, pero en tono menor puesto que su campo de acción es más comercial y parece estar bajo la influencia de casas editoras y de los feudos y camarillas de grupos literarios de la ciudad de Nueva York y universidades cercanas. En consecuencia NYTBR no puede compararse con TLs. Pero a esta publicación bibliográfica - que lo mismo podríamos llamar revista que periódico- ha logrado marcar el cenit y el nadir de la crítica nerudiana en lengua inglesa, posiblemente sin inten- 
tarlo y sin que nadie lo haya notado. En ninguno de los dos artículos a que vamos a referirnos aparece el nombre de Neruda en el título. En el segundo ni siquiera se le nombra.

El cenit lo marca un ensayo de Donald Hall, del 3 de marzo de 1968, página 2. Hall es profesor de inglés, ha publicado un libro de poe. mas, muy bueno, Exiles and Marriages, trabajos sobre Whitman y Marianne Moore y la que se considera la mejor antología de poesía norteamericana e inglesa, Faber Book of Modern Verse, 1965. En su estudio en NYTBR habla de Whitman, de William Carlos Williams, de Louis Simpson. Y el último párrafo:

Martí había insistido a una conferencia de Whitman en 1887 y Whitman es el poeta de esa América que Martí podía adivinar detrás de la América de catedrales y prisiones. Whitman es también el poeta de la América que ama Neruda. Whitman y Neruda tienen mucho en común, los dos son nacionalistas y surrealistas, poetas del deseo y del miedo, poetas del amor y de lo más íntimo del alma, y los dos más grandes poetas del hemisferio.

En cambio, una de las más bajas y estúpidas apreciaciones de Pablo Ne. ruda que jamás hayan aparecido en ningún idioma se debe también al NYTBR y podía haber sido firmada con gusto por Paseyro, quien dada la presente situación política no es extraño que ahora se esté traduciendo al inglés. El artículo a que nos referimos está firmado por un tal Thomas Meehan, es un estallido envidioso y resentido ante el of recimiento del Nobel a Neruda. Data del 21 de noviembre, 1971, p. 81; se titula "Notas sobre Drubnick". Drubnick es Pablo Neruda. Traducción parcial:

El mes pasado, cuando se anunció en Estocolmo que el premio Nobel no había sido otorgado ni a Auden ni a Borges ni a Nabo. kov, a quienes todo el mundo suponía ser los candidatos favoritos, sino a Gregor G. Drubnik, un fabulista búlgaro de 67 años de edad. . No sólo es Drubnik totalmente desconocido en el mundo occidental sino que no lo conocen ni siquiera en Bulgaria. Pero ahora con la versión en inglés de "El porquero intratable"... el lector americano tendrá al fin la oportunidad de examinar por sí mismo la obra de un escritor singularmente aburrido... Si bien los especialistas del mundo entero se sorprendieron de que el envidiado premio le haya sido dado a un oscuro escribidor búlgaro, nadie estaba más sorprendido que el mismo Drubnik que en su 
vida había oído hablar del premio Nobel de literatura... Quizás el peor obstáculo para entender a Drubnik es que insiste tozudamente en escribir en pludnik, un ambiguo dialecto eslovaco... La notable calidad soporífera de sus fábulas puede ser tanto la respon. sabilidad de Drubnik como la de sus traductores... En resumen, tomando en cuenta la oscuridad del pludnik y de sus traducciones, quizá lo mejor que puede hacer el lector norteamericano respecto al recipiente del premio Nobel del presente año, es olvidarse de que jamás oyó mencionar su nombre o el de sus malditas fábulas.

Hemos subrayado malditas porque la palabra usada en inglés, goddam tiene como mejor equivalente una vieja palabra española o la palabra mexicana que ha servido a Paz para largas disquisiciones. El NYTBR no acostumbra a imprimir vulgaridades de esta índole. Al parecer un Nobel para Neruda ofendió a la crítica norteamericana oficial en lo más profundo de su corazón reaccionario.

Es interesante especular sobre el significado de tal ataque periodístico. El Meehan sabe mucho más de Neruda de lo que deja adivinar. El "porquero intratable" suena a "hondero entusiasta" -parodia tonta-. El desprecio hacia el "dialecto" del recipiente del premio Nobel pudiera ser una tardía preferencia anacrónica por el español peninsular. Las alusiones a los traductores culpables de la oscuridad de "Drubnik" en inglés parecen ataques más o menos velados al grupo de poetas que se ha dedicado a traducir a Neruda. Como el New York Times no es ningún inocente en su tratamiento de Neruda es posible afirmar que el articulejo es deliberado. Naturalmente que al NYT le interesa más el prestigio de los EEUU que la difusión de la poesía en español por buena que ésta sea. Por eso el periódico dijo (abril, 8, 1969) que Pablo Netuda puede socavar la reputación de los Estados Unidos con más eficacia que cualquier propaganda política. Afirmó que Neruda influyó en Ernesto Guevara. $Y$ no falta el esfuerzo por hacerlo aparecer un poco ridículo:

Me gusta coleccionar cosas viejas, dice... Esa vieja locomotora que tengo en el jardín me recuerda a Walt Whitman...

Esta misma actitud despectiva se repite en un largo artículo sobre Chile en el magazine dominical del 11 de enero de 1970. El visitante norteño visita a los indígenas en busca de razones para entender su arrebatada conducta. Neruda hace su aparición en la página 89: 
El radical más famoso de Chile es sin duda Pablo Neruda y todos los periódicos y radioemisoras de la América del Sur dieron a conocer que habia sido designado candidato a la presidencia por el Partido Comunista, del que ha sido miembro durante muchos años. Neruda es -y en esto todo el mundo está de acuerdo- el poeta más importante del idioma español, quizá el más grande que este siglo haya producido... Una invitación a su casa en Isla Negra, una playa encantadora a unas dos horas de Santiago puede ser considerada como la invitación de un monarca. Su casa es un refugio... ni siquiera tiene teléfono. . . Los periódicos de la oposición se burlan de su campaña electoral. . . todo el mundo sabe que duerme la siesta de tres a cinco... (Vive) en un grupo de edificios, casi todos de piedra, que desde lo alto dominan una playa fabulosa... Neruda es de origen humilde, viene de la clase trabajadora del sur de Chile, pero ahora se puede notar, debajo de sus pesados párpados, una mirada aristocrática que parece regodearse en su presente posición... nos sentamos en el bar, que como todas las piezas de la casa tiene una pared de cristal que da al mar. . todas las bebidas del mundo en frascos antiguos... en todas partes objetos de arte... para tomar el café pasamos a un salón de mucha etiqueta. . a ardían los leños en el hogar. . otro ventanal al mar. . y los innumerables objetos de arte. Don Pablo sacó su llavero, abrió una puerta en una pared de piedra. . . con una llavecita de plata abrió la tapa de plata de un botellón de cristal tallado... este coñac es solamente para las gtandes ocasiones, es armenio, de vieja cepa...

Pero otras veces el NYT ha publicado artículos inteligentes sobre Neruda, por ejemplo uno de Selden Rodman, "All American", en julio de 1966. Rodman publicó también una reseña de $A$ New Decalde, la traducción de un poeta norteamericano, Ben Belitt y de uno inglés, Alistair Reid.

En cambio, si TLS no consideró conveniente la adjudicación de un Nobel a Neruda, que los franceses les recalcaron un poco tardíamente (Le Monde - The Gutrdian, enero 29, 1972)-. "En una noche fría de la primavera del hemisferio del sur, miles de chilenos llenaron un estudio al pie de los Andes en noviembre de 1970 para celebrat el premio Nobel otorgado a su poeta-embajador Pablo Neruda"), el New York Times se alzó a la altura de la ocasión y dedicó a Neruda una información completa. En la mañana del veintiuno de octubre de 1972 hasta las emisoras locales de los más pequeños pueblos repitieron la noticia, que les llegó a través de servicios sindicados. Al día siguiente el Times 
(Oct. 22, 1971) dedicó a Neruda un pequeño espacio en primera plana - que en este periódico se distribuye con cuidado- y casi toda la página 34. Incluye reportajes de su corresponsal en Estocolmo, un artículo de carácter biográfico y otro por Nathaniel Tarn, profesor de literatura comparada en los eEuU. Comienza con la aseveración de que "Uno de los más grandes conjuntos de poesía de nuestro tiempo ha sido creado en español, y puede ser que en él las más importantes veces sean las de la América española." Este es un juicio amable, pero no escapa a la repetida actitud inglesa de enjuiciar lo americano-español como una continuación peninsular. Opone este artículo a Vallejo, indio peruano, contra Neruda, como el castellano de Chile. Esto muestra una vez más absoluta ignorancia de la realidad americana y la insistencia sajona en linajes étnicos, que son en las tierras de América tan diferentes a los del resto del mundo. A min. gún hispanoamericano se le ocurriría pensar que Neftalí Ricardo Reyes tiene nada de castellano. En general, a partir de 1966 el NYT publica regularmente noticias sobre Neruda. A saber: mayo 29, julio 4, agosto 1 de 1966. El 8 de mayo y el 14 de septiembre, 1967. Mayo 29, 1968. Y 8 de abril del 69 y 11 de enero de 1970, aparte de lo que ha publicado en 1971.

La revista bibliográfica que en los EEUU sigue en importancia al NYTBR es Saturday Review. SR se ocupa ocasionalmente de la literatura latino-americana, aunque su especialista en literatura comparada, Robert J. Clemens, se dedica más consistentemente a los escritores de España, donde parece tener muchos amigos personales. El 22 de mayo de 1965 dio a conocer el proyecto de la Fundación Rockefeller en combinación con las imprentas universitarias para publicar traducciones de libros de la América Latina. La Fundación donó $\$ 225.000$ para los gastos de traducción. Clemens dice que "la mejor poesía de la América española nunca se ha traducido al inglés, incluyendo la de Neruda, un recipiente del premio Stalin" (p. 60). Lo curioso acerca de la insistencia de las editoriales de que pierden dinero con las obras latinoamericanas y por esta razón requieren los subsidios, es que dichas obras no aparecen nunca en los anuncios de descuento de las grandes librerías neoyorquinas que sin embargo venden los libros del famoso Nabokov - el de la fama cuidadosamente cultivada - a precios de ocasión. El proyecto Rockefeller turo como punto de partida una idea nacida a la sombra de Rutgers University. Volviendo a SR y a Clemens, éste, a propósito del premio Nobel, escribe que "de Chile se escogió a Gabriela Mistral en preferencia a su compatriota Pablo Neruda" y al pie de un tetrato del poeta se halla la nota "Un desaire a Pablo Neruda" (Dic. 1965, p. 41). 
También en SR publicó Selden Rodman un artículo sobre Neruda, 9 de julio, 1966, "Un día con Pablo Neruda". Es un trabajo afectuoso $y$ justo en el que cuenta una visita a Neruda en marzo de ese mismo año. Afirma que "Ginsberg mismo" hubiera podido escribir Ritual de mis piernas. Observación con la que Rodman reconoce una nota evidente en la poesía de los "beats", de los cuales Ginsberg es el más notable representante, y es que han leído mucho Neruda; después de todo los "beats" empezaron imitando Poesía en voz alta en los cafetines californianos. El artículo de Rodman es importante porque Neruda mismo analiza el proceso de creación artística y revela sus ideas sobre la crítica y las relaciones entre los escritores y la política. Y el 13 de mayo, 1967, R. G. Mead escribió proféticamente en SR: "El conocido Pablo Neruda y Borges son al presente los autores de habla española mejor conocidos en el mundo de habla inglesa... Ambos han sido propuestos para el premio Nobel y quizá algún día uno de ellos reciba ese galardón". En el primer número de septiembre del mismo año, M. L. Rosenthal, comentando la traducción Tarn de Maccbu Piccbu habla de la dinámica múltiple del poema y de "Su estructura sinfónica". También debe recordarse que con motivo del Congreso PEN en junio del 66 SR publicó un retrato de Neruda con Grass, Spark, Silone, mencionando que Neruda y Fuentes eran delegados al Congreso.

Con motivo de la concurrencia de Neruda al congreso del PEN se publicaron varios artículos. El más conocido es el de Newsweek, junio 27, 1966, p. 96, porque se reprodujo en Hispania:

Si hubo una figura que destacó sobre todas las demás, ésa fue la del gran chileno Pablo Neruda, que en los últimos años ha ejercido una gran influencia sobre los poetas jóvenes de América. Neruda es comunista pero esto a nadie le importaba... (Es) un símbolo de la literatura ecuménica, un representante de la fuerza trans. cedente del arte. En una lectura pública en el Contro de Poesía de YMHA, ante un público que llenaba el recinto, muchos de los presentes no pudieron contener las lágrimas y Neruda recibió una ovación atronadora. Después dijo: "Estoy a favor de los poetas y la poesía. Estoy a favor de la razón".

Hay en Evergreen, una revista de vanguardia, un buen artículo sobrr Neruda, si es que puede llamarse artículo. Se titula "Llega el GLP'. GLP es la sigla de Greatest Living Poet (El más importante poeta vivo). Es una especie de boceto en que se dice de buen humor que Neruda se merece cuatro premios Nobel pero que no le han dado ninguno: 
Se veía en muy buena condición física, carnoso y lleno de vida. La piel color coñac y los dedos de gamuza típicos de los grandes derrochadores y de los que se aprovechan de lo mejor de la vida... Nada de Whitman. Ojos cuadrangulares bajo pesados epitelios, largos párpados, agudos y abultados, los ojos de un bandido que ahora vive en el lujo... un sólido trozo de aristocrática cordia. lidad... Belitt es magnífico... Admiro sus traducciones que nos trasmiten - si es que pueden con'cordar estos vocablos- un encrespamiento hinchado y sonoro, mientras que Neruda en el original es seco, trágico y español.

Por lo menos después de habernos dicho que el traductor es mejor que el poeta, nos lanza una frase encantadora y lapidaria: Neruda es "la gran anaconda del lenguaje'. El autor es Donald Newlove.

Debe mencionarse a propósito de revistas la tarea personal de Robert Bly, con The Fifties, "una revista de poesía y opiniones", con traducciones a cargo de "la más joven generación de América - la generación de los cincuenta- de la cual la revista toma su nombre". Anunció el número VII "dedicado a Neruda, de Chile, que algunos creen ser el más importante poeta vivo". Es decir, que entre loṣ jóvenes de los Estados Unidos, el poeta vivo merecedor de todo honor es Pablo Neruda. La revista de Bly comenzó a publicarse en 1959, pero solamente hemos logrado ver el número 2. De cierto se puede afirmar que hay centenares de referencias a Neruda escondidas en revistas y periódicos en inglés. Una suerte de fama subterránea, a espaldas de la calculada frialdad de los claustros universitarios. A veces los autores andan un poco confundidos en lo que se refiere a escuelas literarias; "el único gran representante que queda del modernismo es Pablo Neruda que anda detrás de la cortina de hierro buscándose a sí mismo y que a lo mejor nos va a dar una nueva expresión y un nuevo lenguaje para substituir el "ultramo. dernismo" de su Residencia en la tierra" (Shenandoab, 1952, p. 70). Adam dio a conocer a Neruda a los jóvenes de Londres en 1948, (marzoabril) con varios trabajos de jóvenes especialistas. Ben Belitt, veinte años después traductor de Neruda, llevó su nombre hasta Chicago, en Poetry, 1952. Hay además artículos sobre Neruda, en revistas como Visión, diciembre de 1956, mayo 1961. En Berkerley Review, los artículos de Fernando Alegría en 1957. The Nation (V. 206, p. 417), publicó en 1968 el prólogo de Robert Bly a su traducción de $V$ einte poemas. Pero las revistas se han distinguido, más que nada, en dar a conocer poemas sueltos de Neruda. 


\section{LOS LIBROS}

Nos vamos a referir a los libros de texto, que tienen un impacto efímero y que se transcriben con más preocupaciones en ganancias rápidas que en permanencia crítica. Pero entre los libros de texto los más importantes son los de historia porque caen en manos de estudiantes que no están interesados en la América española porque se habla en ella un idioma que están aprendiendo, sino porque sus intereses son universales. Al nivel de la escuela secundaria el de más circulación sea posiblemente Latin America. The Development of its Civilization, de Helen M. Bailey y Abraham P. Nasatir, N. J., 1960 (hay varias ediciones). Para edifica-. ción de jóvenes inocentes (o no tan inocentes puesto que se encuentra a veces como texto en universidades) afirma que los poemas de Neruda son "difíciles de entender. . pero tiene muchos imitadores en toda la América Latina" (p. 616). De más circulación y más prestigio es el libro del inolvidable especialista Hubert Herting, $A$ History of Latin America, del cual se han hecho a partir de 1955 catorce reimpresiones, la última, revisada, es de 1968. Herring menciona los ataques de González Videla a Neruda "uno de los mejores poetas de América" (p. 669) y repite que "es un estilista de gran talento que ha influido en España y en la América Latina en los últimos 30 años" (p. 685). 'Otro libro de circulación en Norteamérica es Latin America, A Cultural Oulline (Harper, 1965) del dedicado latino-americanista británico Stephen Clissold, que escribe "César Vallejo, y ahora Pablo Neruda, de extraordinarios dones, son quizá los más famosos del grupo de poetas que han abrazado el comu. nismo..." (p. 98). El ejemplo clásico de crítica literaria (y ya mencionado en RHM en la primera bibliografía nerudiana en EEUU, la de Rosembaun), es The Modernist Trend in Latin American Poetry, de D. S. Craig, California, 1934. Craig estudia la traducción que hizo Netuda de un corto pasaje de Whitman y cree a Whitman más interesado en el alma que en el cuerpo; Neruda es el caso contrario ( p. 331). Craig explica "Farewell" y por razones ajenas a la literatura, menciona que Neruda en este poema se refiere a un "fruto del amor ilícito" (p. 333). Traduce bastantes composiciones de Neruda.

Si Craig es importante por ser el primero en la lista, la Antología del Instituto Internacional de Literatura Iberoamericana (Hespelt, Her. man, ed. An Antbology of Spanish American Literature, Crofts, 1946), que prepararon Leonard, Reid, Crow y Englekirk bajo la dirección de E. Herman Hespelt (uno de los más dedicados latinoamericanistas que ya 
en 1921 era profesor titular de español en Elmira College, en uno de los apartados rincones del estado de Nueva York) es fundamental y básica para poder comprender el impacto de los autores hispanoamericanos en los EEUU. Fue durante años la única accesible y la única recomendable. Fue texto en escuelas secundarias, por ejemplo en Somerville, Nueva Jersey, el primer sistema educacional donde se empezó a enseñar español en escuelas primarias, hace más de treinta años. Con ella generaciones de estudiantes norteamericanos se aprendieron de memoria poemas como el "Número 15" y "Barcarola".

En 1949 Arturo Torres-Rioseco incluyó un estudio sobre Neruda en su New World Literature. Tradition and Revoltpin Latin America (Cali. fornia, 1949). De Pablo Neruda dice que "es el más fiel representante del alma indígena de Amética". Incluye fragmentos de poesías con traducciones literales, algunas de Ruth Werner. Una muy buena versión de "Apogeo del apio" se attibuye a Kenneth Edwards, también "Explico algunas cosas", "Canto para Bolívar". De este año data también la antología de Selden Rodman, 100 Modern Poems (Farrar, 1949). De esta época es otro libro de amplia circulación, el de Whit Burnett, The World"s Best (Dial, 1950) que incluye la traducción de Maccbu Piccbu por Angel Flores (p. 355-367).

En 1960 apareció un libro empleado continuamente en clases de inglés a todos los niveles, en todos los EeUU. Se trata de The Poem Itself (New York, 1960), preparado por Stanley Burnshaw. La selección española es excelente y para ella fue asesorado por los notables hispanistas Dudley Fitts y John F. Nims. De este libro hay muchas ediciones en rústica y se halla a la venta en cualquier librería, lo mismo en supermercados que en los pequeños establecimientos académicos. Entre los franceses trae a Nerval, Eluard y Char. Entre los alemanes a Bertolt Brecht. Varios españoles y brasileros, y de los nuestros Neruda, Vallejo y Florit. De los italianos Ungaretti, Montale y Quasimodo. De Neruda incluye "Puedo escribir los versos..." y "No hay olvido..." con la traducción literal y explica. ción de texto de Paul P. Rogers. Es importante echar una mirada somera a la versión de "Puedo escribir..." para poder comprender cómo funcionan los traductores comerciales en lengua inglesa, que al parecer se dedican a la tarea más por lucro que como ejercicio estético. Roger expone:

(1) Puedo escribir los versos más tristes esta nocbe. Siguen a esta declaración dos líneas bonitas pero bastante ordinarias. Como el autor sabe esto, las pone entre comillas: (2) escribir, por ejemplo: 
"La noche está estrellada" (3) y tivitan, azules, los astros, a lo lejos".

La traducción es literal y a la altura estudiantil. Pero el público que adquiere la traducción de Merwin, o lo que es peor, el millón de lectores del New York Times del 22 de octubre de 1971, en su información va. riada y amigable con motivo del premio Nobel, se enfrenta con "the night is shattered"' (la noche está hecha añicos). En esto estamos haciendo hincapié porque a menudo en la América española se leen solamente publicaciones de carácter comercial y se desconoce la complejidad del mundo cultural de Norteamérica. El que haya malas traducciones de Neruda no quiere decir que éste sea mal conocido. Existe una conciencia cultural norteamericana, exacta y bien informada, que aunque pocas veces sale a la superficie - el artículo ya citado de Hall es un ejemploconoce al verdadero Neruda y lo puede leer, si no en el original, por lo menos en transposiciones aceptables. S. Rodman publicó en 1970 un libro de viajes titulado South America of the Poets, en que también habla de Neruda. Refiriéndose a este libro, en particularmente a Neruda, escribió P. P. Witonski en National Review, enero 12 de 1971, que "De los poetas que hablan del amor, es el más grande de este siglo".

Interesantes son los libros de dos grandes críticos ingleses. Uno, C. M. Bowra, ha escrito The Creative Experiment, en circulación desde 1948 en varias ediciones inglesas y americanas, en el que estudia el manejo de la imagen en Neruda comparándolo con la técnica de Shelley. Bowra cita a Neruda en español, pero al pie de la página transcribe la traducción de Angel Flores. Aún más importante que este libro es otro del mismo autor, Poetry and Politics, $1900-1960$ (Cambridge, 1966). Cree que la acción política puede ser el resultado de un proceso deliberado en muchos autores y éste es el caso de Bretch y Êluard, pero que en otros es una tendencia innata:

Esto es lo que sucede con el notable poeta chileno Pablo Neruda (n. 1904) que todavía se mantiene muy activo y que fue desde el día de su nacimiento un genuino hombre del pueblo. Su padre era empleado de ferrocartiles y él mismo aprendió muy pronto lo que significa ser pobre... A pesar de todo, como han hecho muchos hombres de talento, Neruda logró educarse y escribir cinco libros de poemas antes de cumplir los veintiún años. . Chile no ha tratado tan mal a Neruda como Rusia a Mayakovsky o a Pasternak. Neruda es parte de una oposición vociferante pero ha podido seguir escri- 
biendo y publicando. Su producción es enorme, aunque la mitad sea mediocre, política retórica sin imaginación o percepción. Pero la otra mitad es notable desde cualquier punto de vista y la línea divisoria entre lo bueno y lo malo no se descubre tanto en un poema como en la diferenciación entre poema y poema, parecería que Ne. ruda es mejor poeta en unos días que en otros... No es que ignore las normas literarias por el placer de ignorarlas, es que ni siquieta sabe que existen.

Bowra, que se siente asqueado por "la mala poesía nerudiana de doctrinas marxistas", tiene que confesar que "es un poeta asombroso, de un ímpetu sin paralelo en este siglo". Y aunque todo eso de la "mala poesía nerudiana llena de doctrinas marxistas" ha pasado a ser el cliché favorito de tanto crítico que cae bajo la égida de la política antisoviética internacional o de las traducciones subvencionadas, el caso es que todavía nadie ha demostrado cuál es la mala poesía de Neruda. Ni el poder soviético depende de Neruda, ni la poesía política de Neruda es tan mala como se afirma repetidamente.

Otro de los críticos ingleses ahora en el apogeo de su fama y pro. ducción es George Steiner, quien se ocupa de Neruda en Language and Silence (Atheneum, 1967). Dice Steinet "Para Pablo Nerunda (sic) la ideología comunista representa la promesa de una ideología vengativa". Al mencionar a Pound en el mismo trabajo nos afirma que "Pound no fue un fascista, sino que se aprovechó de la circunstancia y los ornamentos del fascismo para adaptarlos a sus extrañas teorías económicas". Es decir, que el fascismo de Pound es el resultado de un capricho personal y de su ignorancia de una economía científica, y a la vez, el comunismo de Neruda es el resultado de su reacción al coloniaje constante en que vive la Amé. rica española respecto a los Estados Unidos, porque no hay otra manera de interpretar lo que insinúa Steiner cuando menciona una "ideología vengativa".

También aparece Neruda en relación y por motivos de su política en Political Forces in Lativn America, editado por Burnet y Johnson, una especie de texto-antología (California, 1970, segunda edición). En un capítulo uno de los editores, Kenneth F. Johnson, proclama a Nicolás Guillén como el epítome y ejemplo del antiamericanismo latinoamericano y tiene a bien citar a Neruda en relación con la violencia que es "un aspecto central de la psicología de la América española". Afirma que esta violencia es una "constante ideológica" sin mencionar naturalmente que los Estados Unidos son tan violentos como cualquier otro pais. 
La prueba documental de su afirmación la proporciona Neruda en la "Oda a la calle San Diego".

En contraste, la crítica literaria norteamericana parece estar ahora dispuesta a hablar de Neruda claramente. Nancy Willard, en Testimony of the Invisible Man. (Universidad de Missouri, 1970) incluye un artículo titulado "Radiant bread for the sun of man: Pablo Neruda" (p. 83-109) También incluye estudios sobre Rilke y William Carlos Williams.

Entre los pocos críticos ingleses dedicados a la literatura de la América española hay que citar a Jean Franco, la autora de An Introduction to Latin American Literature, Cambridge, 1967. Su capítulo sobre Neruda es informativo y ponderado, las traducciones son las más fieles y poéticas que las que se hallan en libros pseudopoéticos. Con Jean Franco hay que citar a otro gran hispanista de Gran Bretaña, Robert Pring-Mill, de Oxford, que escribió el precioso exordio a la traducción que hizo Tarn de Maccbu Miccbu. También presentó un estupendo trabajo sobre Neruda en el Congreso de Hispanistas de México.

Se puede añadir que Neruda aparece en The Columbia Encyclopedia, III edition, Columbia University Press, 1963. También en la Encyclopedia Americana, edición internacional de 1966, además de haber sido incluido, naturalmente, en $W b o^{\prime}$ ' in Latin America (ed. R. Hilton). Lo notable y sorprendente es que se le incluye en The Columbia-Viking Desk Encyclapedia (Columbia University Press, 1953, con la siguiente nota: "pseud. de Naftalí (sic) Ricardo Reyes, 1904-, poeta surrealista de Chile, notable por sus atrevidos experimentos en verso.

\section{TRADUCCIONES SUELTAS}

Hay tantas traducciones de Neruda y en presentaciones tan diversas que vamos a dividirlas en traducciones sueltas y en libros traducidos. Según el artículo del New York Times del 12 de octubre del 71 hay doce libros de traducciones de Neruda. En realidad nadie sabe cuántos poemas $-\mathrm{y}$ a lo mejor ni cuántos libros- han aparecido en inglés. Hay profesores de literatura inglesa que aseguran - citando versos- que han leído poemas de Neruda que no saben en dónde, o que juran haberlos leído en revistas que jamás han publicado una línea de Neruda.

Las traducciones sueltas son aun más importantes que los libros por. que muchas datan de la época presubvencionada, cuando los escritores que se dedicaban a traducir lo hacian por amor y no por dinero. Como señala 
Yulan Washburn (Hispania, 1968, p. 948) ahora las traducciones del español al inglés son un torneo que atrac a todo el mundo. $\mathrm{O}$ mejor dicho, una especie de becerrada a campo abierto.

Al parecer el primero que tradujo a Neruda para revistas norteamericanas fue J. L. Grucci, quien también incluyó a Neruda en libro. Publicó fragmentos del Canto General de Cbile en American Prefalces, de la Universidad de Iowa a fines de 1942 y después "Es cierto, amada mía" en Faniasy, Pittsburgh, No. 26, también en 1942. Fantasy, publicada en Pittsburgh, fue en un tiempo muy importante. Además de haber publicado la traducción de "Es cierto, amada mía...", publicó también una reseña de Willis Knapp Jones sobre el libro de Grucci (No. 27, 1943, p. 143). Dice Jones que los poemas de Neruda habían sido publicados anteriormente en American Prefaces y en New Mexico Quarterly, cuenta que después de leer varias veces el "Apogeo del apio" t"uve que buscar el "original y pude convencerme de que el traductor había traducido solamente lo que había leído". Para este número de Fantasy también tradujo Grucci "7 de noviembre. Oda a un día de victorias".

En 1943 Mercedes de Acosta tradujo "7 de noviembre..." para Tomorrow, N. Y., V: II, mayo de 1943. La traducción de Hays de Alturas de Macchu Picchu, está en The Tigers' Eye, N. Y., V. 1, octubre de 1948. En 1949 empieza la larga serie de traducciones de Mlasses and Marinsiream y el 4 de abril de 1950 publican el capítulo X del Canto geveral, traducción de Waldeen, y en otros números traducciones de Bernstein, Waldeen, Brittain y A. L. Lloyd, o por lo menos firmadas con esos nombres. De Waldeen es "Amar Amética" y "Los ríos acuden" en The California Quarterly, 1952.

En 1958 New World Writing (N. 14), una revista de avant-garde que publicaba The New American Library, publicó una traducción de la "Oda a la pereza", de William Carlos Williams. De todos los poetas que han trabajado con la poesía de Neruda, Williams es el único verdaderamente importante. Amigo de Pound, de Marianne Moore, de Yeats, publicó su primer libro de poemas en 1913. Su más famosa colección es Los libros de Paterson y se han publicado varias selecciones de su poesía. Es uno de los grandes poetas de los EEUU; cuando joven se le ocurrió traducir a Quevedo y ya estaba viejo cuando tradujo a Neruda. Trabajando en el proyecto piloto de Rutgers, fue Eugenio Florit quien sugirió que se tradujeran las $O d a s$ en preferencia a otras composiciones y fue mi idea que se le enviaran a Williams. El resultado fue un poema en inglés que retiene toda la gracia del original y que es a la vez poesía legítima, (New World Writing, Mentor, N. 14, p. 99, 1958). Debe 
añadirse que WCW es uno de los poetas que más influencia han ejercido sobre la joven poesía norteamericana actual. Y el que más conmo. vedoramente ha confesado su admiración por Neruda.

The Nation, en 1960 (V. 191, p. 350) incluyó "Juventud", en traducción de Belitt. En 1961 "Melancolía en las familias", de Clayton Eshleman (V. 192, p. 337) y "Procesión en Lima", de Belitt (p. 337). También de 1961 es "Poemo número diez", por Jerome Rothenberg (V. 193, p. 61). En 1967, "Soneto XXIX", en texto bilingüe, traducido por Belitt. Y en 1968 "Mentiras", en traducción de Bly (V. 206, p. 417).

Robert Bly es una de las figuras más interesantes entre los jóvenes norteamericanos, dedicado, abierto, generoso. En 1959 empezó a publicar una revista llamada The Fifties, "un magazine de poesía y opiniones". Con el segundo número incluyó una hoja suelta en la que anuncia el contenido de los números I-VIIT. El número siete estaría dedicado a Neruda "de Chile, que muchos creen el más importante poeta vivo del mundo, y a César Vallejo, del Perú". No hemos podido encontrar este número, pero The Fifties pasó a ser The Sixties. En el número 9, primavera de 1967, Bly publicó una entrevista con Neruda que se titula "Una conversación sobre Miguel Hernández". Este grupo de poetas jóvenes editaba las miniaturas de Hawk's Well Press. En el número uno, sin fecha( 1960?) traduce "Oda al niño de la liebre", J. Rothenberg, quien era el alma de esta imprenta. Mejor en alemán que en español, Rothenberg dio a conocer en EEUU a Paul Celan.

En 1962 Belitt publicó en Evergreen (enero-febrero) una versión de "Infancia y poesía". Bly y Wright "Melancolia en las familias", y "Compañeros de viaje" en The Paris Review, 1966; Belitt "Amores", "Matilde"... en Mundus Artium, revista de la Universidad de Athens, Ohio. Y Cinna Lomnitz tradujo poemas de Estravagario para el Arizona Quarterly de la Universidad de Arizona, los dos en 1967. En 1971 una revista de combate, especie de boletín de Nortb American Congress on Latin America, Inc. (Vol. 5, no. 6, oct.) trae en la postada "The United Fruit Co." del Canto general, en una traducción clara y literal.

La historia de la poesía joven norteamericana está en las revistas pequeñas, de poca circulación, especializadas, idealistas, hechas con amor. Es la misma gente que publica los pequeños magazines europeos donde se dan a conocer los principiantes y se inician los cambios. Estas son las revistas que publicaron a Neruda y ésta es la gente que lo lee: un público informado, selectivo, apartado del bullicio de las publicaciones comerciales. Cuando una de estas revistas menores, publicada en una de las más alejadas esquinas del continente, menciona a Neruda, lo nombra 
con toda naturalidad. Por ejemplo en The Far Point No. 3, de 1969, de la Universidad de Manitoba se habla de Robert Bly y se dice que le gusta hacer preguntas inopinadas: "En 1969 interrogó a Neruda, de sopetón ¿no cree usted que ha vivido otra vida anterior en este mundo?" Y nada más sobre Neruda. El autor del artículo da por descontado que todo el mundo sabe quién es Neruda.

También han aparecido muchos poemas sueltos en revistas inglesas, de hecho antes que en las norteamericanas. En Left Review, abril de 1937, "A las madres de los milicianos muertos", por Nancy Cunard, de excéntrica familia inglesa. G. S. Fraser y George Elliot tradujeron para Poetry de Londres, y ellos mismos con G. R. Coulthard colaboraron en el homenaje a Neruda de Adam International Review de 1948 en un número doble (XVI, 181-182) que al parecer es la única mención inglesa importante que se hace al alcance del público antes de que Neruda recibiera su doctorado bonoris causa de la Universidad de Oxford. Obviamente, dado que Neruda recibió su doctorado en 1965, está claro que fue mucho más importante entre los escritores ingleses de lo que hacen suponer las publicaciones o artículos sobre sus libros. Para Adam, Frase tradujo el texto completo de El babitante $y$ su esperanza. Fraser y Coulthard también tradujeron Las furias y las penas para Poetry de Londres en 1948. En 1965 Pring-Mill publicó en The Oxford Magazine el poema inicial del Canto general, cap. III. En Encounter, dic. 1967, Alistair Reid publicó doce poemas. En 1968 tenemos las traducciones de Afrasian, núm. 1, de Merwin, Kerrigan, Reid y Tarn. Hay además poemas sueltos en el TLS. En Night Batbers (Cape, 1970) Ted Walker incluyó, con sus propios poemas, traducciones de Verlaine, Rilke, Montale, Hoderlin, Lorca, Lope y Neruda. Todas sus traducciones son fieles al original.

\section{ANTOLOGÍAs}

Neruda, desde luego, está incluido en muchas antologias. Dos muy importantes, no sólo por su derecho de precedencia, sino también por la calidad de las traducciones, son la de Dudley Fittss y la de Hays. La primera, Anthology of Contemporary Latin-American Poetry, New Directions, 1942, trae traducciones de H. R. Hays, Angel Flores y el mismo Fitts. Todo lo que trae esta antología es de excelente calidad. La de H. R. Hays, Twelve Latin American Poltas, Yale, 1943, es también un libro superior e informado. Mildred E. Johnson publicó Swan, Cygnets 
and Owl, en anthology of Modernist poetry in Spanish America, University of Missouri, 1956. Trae un prólogo de J. S. Brushwood. Las traducciones de Johnson tienen un raro sabor anticuado. También de un viejo estilo son las que incluye Willis Knapp Jones en Spanish American Literature in Translation Ungar, 1963, a quien le cabe el honor de haber sido el primero que escribió sobre Neruda en inglés. En los últimos tiempos alcanzan gran circulación dos libros de J. M. Cohen, Latin American Writing Today, Penguin, 1967 y Poetry of this Age, 1908-1958, (London 1960) que no habla mucho de Neruda. Acompanada de gran publicidad vino Tri-Quarterly Antbology of Contemporary Latin American Literature, Dutton, 1969, con traducciones de Bly, Wright, Parr y Belitt, es decir, reprodujo traducciones previamente publicadas. De Christopher Logue, "Twenty Love Poems", basados en Pablo Neruda, en Songs, (Hutchinson, Londres, 1959), que Merwin lista en su Twenty Love Po'ems.

\section{Libros. ('TRADUCCIONES)}

Antes de mencionar las traducciones reunidas en libros, vale la pena hacer un pequeño inventario de las más conocidas reseñas bibliográficas que de esos libros han aparecido en inglés:

Residencia en la tierra, traducción de Angel Flores: New Yorker, dic. 21, 1946 (s. n.); New York Times, enero 26, 1947 (Milton Bracker); The Nation, feb. 8, 47 (Rene Blanc-Roos); San Francisco Cbronicle, feb. 16, 47 (George Snell); Canadian Forunm, abril, 1947 (Margaret Arvison); Saturday y Review, abril 26, 47 (Muna Lee); Poetry, junio, 1947 (Dudley Fitts); Cbicago Sun, julio 20, 47 (Kienneth Rockwell); New York Herald Tribune, nov. 23, 47 (B. D. Wolfe).

Selected Poems, traducción de Ben Belitt: Cbristitun Science Monitor, dic. 21, 1961 (Juan Marichal); NYTBR, enero 14, 1962 (Manuel Durán); The Nation, sep. 15, 62 (Clayton Eshleman); New Yorker, nov. 17, 62 (Louise Bogan).

Alturas de Maccbu Piccbu, traducción de Tarn: Library Journal, mayo 1, 1967 (J. H. Wolf); NYTBR, mayo 21, 67 (Dudley Fitts); Book Week, mayo 28, 67 (Sandra Hochman); Saturday y Review, sep. 2, 67 (M. L. Rosenthal); Virginia Quarterly Review, otoño, 67.

We are mony, traducción de Alistair Reid: New Stateman, nov. 3, 1967 (Julian Symons); Library Joumal, 1968 (Bill Katz). 
A New Decade, traducción de Belitt-Reid: Library Journal, sep. 1, 1969

(D. Curley); Texas Enterprise, sep. 21, 69; NYTBR, oct, 26, 69 (Selden Rodman); Christian Science Monitor, nov, 18, 69 (Victor (Howes); Commonweal, nov. 18, 69 (Ronald Christ).

Todas las anteriores: "Neruda in English", Caribbean Review, V. I, 1969. (B. Wallenstein).

Veinte poemas de amor, traducción de Merwin; Choice, abril 1971; New Stateman, julio 17, 1971.

No es posible recomendar ninguno de los libros que circulan hoy en inglés por razones que trataremos de examinar. Ningún libro es suficientemente bueno. Probar esta afirmación es tarea de cotejos y comparaciones, así que nos limitaremos a unos cuantos ejemplos aislados. Como hemos notado al citar a Newlove en su ensayito de Evergreen, hay comentaristas que prefieren al Neruda interpretado por los traductores porque el original es seco y duro. No ha habido un Pound capaz de traspasar a Neruda a un idioma leal y poético, o de hacer por él lo que Arthur Waley hizo con la poesía china, aunque al parecer eso es lo que han intentado los traductores de Neruda: consagrarse como poetas poetizando a Pablo Neruda. Para colmo de males las traducciones de Neruda que más circulan en los EEUU son las de Ben Belitt, y estas traducciones son atroces.

Trataremos de ocuparnos de las traducciones en orden cronológico. El primer libro en que se incluye a Neruda es el tomito pionero de Craig, pero la primera edición para un público poético, sin fines didácticos es la de Grucci, que data de 1942. El primer volumen propiamente dedicado a Neruda es la traducción de Residencia y otros poemas que hizo Angel Flores. Es decir, Neruda ha sido conocido, leído, comentado y traducido en inglés, en un periodo que abarca más de treinta años, - hasta ahora.

Las traducciones son, en orden cronológico, con el año de aparición de los libros correspondientes:

1942 Three Spanish American Poetas, Pellicer, Neruda, Andrade. Sage Books. Albuquerque, New Mexico. Traducción de Joseph Leonard Grucci, quien también escribe una nota introductoria, breve e informativa.

1946 Residence on Earth and Other Poems, traducción de Angel Flores. New Directions, 1946. Incluye España en el corazón, parte del Canto general de Chile y poemas que llegan hasta 1944. 1948 Three Material Songs (Tres cantos materiales) También tra- 
ducción de Angel Flotes. Aguafuertes de Nemesio Antúnez, New York 1948.

1951 hasta 1953 Let the Rail Splitter Awdke and Otber Poems Masses and Mainstream. Cuaderno humilde, impresión barata pero todavía muy clara, miscelánea reproducida de la revista Masses and Mainstrewm. Probablemente varias reimpresiones, al parecer de distribución gratuita.

1961 Selected Poems of Pablo Nerudo, Traductor Ben Belitt, ex. celente prólogo de Luis Monguió. New York, Grove, 1961. Hay una edición Evergreen de 1963 de la cual hemos consultado la cuarta reimpresión.

The Elementary Odes of Pablo Neruda. Traducción de Carlos Lozano, Cypress, N. Y. Prefacio de Fernando Alegría. Preciosa edición bilingüe.

1962 Residence on Eearth, selección de poemas traducidos por Clayton Eshleman. San Francisco.

1965 Bestiary, traducción de Elsa Neuberger, Harcourt-Brace. Grabados de Frasconi, presentación de Angel Flores. Hay una edición Spiral de la que se conservan pocos ejemplares.

1966 The Heigbs of Maccbu Piccbu. Londres, 1966. En Nueva York se publicó una edición de Farrar, Strauss y Giroux, 1967. Tradujo Nathaniel Tarn. Prólogo del hispanista inglés Robert Pring-Mill.

1967 Twenty Poems. Traducciones de Robert Bly y James Wrigth. Wisconsin, 1967, y Londres, 1968. Como prólogo trae interesante entrevista a Neruda.

1968 We are many, Londres y Nueva York, 1968. Traductor Alistair Reid. Un grupo de poemas cortos seleccionados por el mismo Neruda. Edición cuidadosa y bien presentada.

1969 A New Decade (Poems, 1958-1967) Edición y prólogo de Ben Belitt. Grove Press. Traducciones de Belitt y Alistair Reid. The Early Poems New Rivers Press. Traducciones de David Oss. man y Carlos B. Hagen. Dibujos de Lucas Johnson. Incluye poemas publicados entre 1923 y 1926.

Twenty Love Poems and a Song of Dispair, Londres. Traductor W. S. Merwin. Hay edición encuadernada y en rústica. 1970 Selected Poems. Edición a cargo de Nathaniel Tarn, traducciones de Tarn. Merwin, Reid, Kerrigan. Londres, Cape. 1972 Selected Poems. Editor Nathaniel Tarn. New York, Delacorte 
Press. Al parecer la versión norteamericana del libro publicado por Cape en 1970.

Neruda y Vallejo. Selected Poems. Edición y traducción de Robert Bly. También incluye traducciones de John Knoepfle y James Wright. Boston, Beacon Press. Para estos dos últimos libros véase la reseña bibliográfica de Alexander Coleman en NYTBR, mayo 7, 1972, p. 4.

Extravagario, traducción de Alistair Reid, Londres, Cape. Edición encuadernada y edición en rústica. Véase TLS, julio 21, 1972, p. 838.

En resumen, a Neruda se le ha traducido al inglés en libros completos, en colecciones y hasta en fragmentos, en revistas dé poesía y en cuadernos de propaganda, como poesía pura, como poesía obrera o para ayudar a la república española. Pocas de sus traducciones son buenas y algunas son sorprendentemente malas. Algunos reseñadores, generalmente ingleses, no temen señalar estas deficiencias, pero los norteamericanos, que en cuestiones de críticas son tan esclavos de la camarilla como los hispanoparlantes, prefieren no notarlas. Inclusive hay casos en que una buena traducción, como la de Carlos Lozano, parece haber sido deliberadamente ignorada. Los críticos de habla española despedazan a los traductores de su propio y común origen, pero casi nunca se detienen a examinar las versiones inglesas que se hacen de nuestras obras maes. tras. Los norteamericanos se alaban los unos a los otros con los ojos fijos en las casas editoriales. Los ingleses son más veraces, pero se ayudan mutuamente y se tratan con admirable cortesía recíproca.

Tan interesantes, o quizás mucho más importantes que las traducciones escritas para un público general, son las traducciones de propaganda, que se empeñaron y que todavia persisten en dar a conocer a Neruda exclusivamente por sus actitudes y pronunciamientos políticos. Estaban dedicadas a un público más interesado en pronunciamientos antiimperialistas y en los cambios sociales que en la poesía. Esta es la audiencia de Masses and Mainstream que publicó muchos poemas de Neruda a partir de 1950, en una época notable por su falta de respeto a los derechos civiles, en los años del llamado "macartismo". Por eso algunos de los nombres empleados por los traductores suenan a pseudónimo. Los poemas fueron después recogidos en un pequeño volumen. Este librito comienza con un prólogo de Samuel Sillen, en donde se dice que "Walt Whitman afirmó que un gran poeta al servicio del pueblo podría lograr que cada una de sus palabras hiciera correr sangre. Esto es cierto 
respecto a Pablo Neruda". A continuación publica la traducción de J. M. Bernstein del discurso que leyó Neruda en el Congreso Latinoamericano de Partidarios de la Paz, en México, 1949. (Según la bibliografía de Hernán Loyola hubo una edición clandestina del Partido Comunista de Chile con el título $\mathrm{Mi}$ país, como ustedes suben. No está incluido en las $O C$.) La única nota literaria importante de este discurso es una referencia a un Fadeyev que afirmó que si las hienas pudieran escribir, escribirian como T. S. Eliot o como Sartre. Neruda dice que eso es un insulto al reino animal.

Las traducciones de Masses and Mainstream son muy efectivas pero muy descuidadas. No hay datos de origen ni títulos originales. Las composiciones han sido escogidas por su vigencia revolucionaria, la llamada al motín y a la protesta, literatura de combate. No se respetan párrafos ni puntuación. Con el fin de hacerlos más eficientes se han condensado, y se nota un deliberado esfuerzo por traducir a Neruda, no al inglés, sino al estilo de Whitman. Por ejemplo: de la primera estrofa de "que despierte el leñador"

Al oeste de Colorado River
hay un sitio que amo.
Acudo alli con todo lo que palpitando
transcurre en mí, con todo
lo que fui, lo que soy, lo que sostengo.

En inglés resulta, (y la traducción es de Waldeen)

West of the Colorado River is a place I love

I turn towards it, with everything that lives in me, with all that I was, and am, and believe.

(Al oeste de Colorado River hay un sitio que amo./ Acudo allí con todo lo que vive en mi,/con todo lo que fui, lo que soy, lo que creo.) El título de este poema, que le da nombre al libro, es un verdadero acierto en inglés, idioma en que tiene más connotaciones de exhortación patriótica que en español; en la literatura de Norteamérica el Great Rail Splitter es Abraham Lincoln. A pesar de los telescopiamientos y la es. trofación caprichosa, el poema es muy poderoso cuando se lee en inglés. Las posturas políticas, altisonantes y gastadas en español, renacen con una fuerza extraordinaria en las manos de los bien entrenados traductores de Masses, que al parecer no solamente tenían un buen dominio del español, sino que conocían a su pueblo y su propia literatura. Casi se 
diría que puede haber más de un traductor, uno para traducir del español y otro para pulirlo y adaptarlo a un inglés culto y combativo.

La traducción de "Los muertos en la plaza", ("La arena traicionada", III) bajo el título "The Dead in the Square", es muy efectiva poesía de propaganda, más fuerte e inesperada en inglés que en español. Lleva la firma de Robert Brittain. A. L. Lloyd no es tan bueno en "Un canto para Bolívar". "El fugitivo", firmado por Waldeen -quienquiera que éste haya sido- es también un bien logrado ejercicio de barricada.

También trae una traducción directa, y por lo tanto con toda la fuerza evocadora del original, de las Alturas de Maccbu Piccbu, firmada por Waldeen, nombre a todas luces ficticio. Otro traductor de nombre, - si no ficticio por lo menos incompleto-, se firma Isabel y tradujo una composición dedicada a Howard Fast, que todavía está inédita en español y que empieza "I speak to you, Howard Fast. You who are jailed..." ("A ti me dirijo, Howard Fast. Tú que estás preso...") y que termina con "Today's prisons will be tomorrow's victory" ("Las cárceles de hoy, serán mañana la victoria").

\section{Los Traductores}

Dada la riqueza y variaciones de la poesía de Neruda y la plétora de traducciones, la tarea de comparar textos es tediosa y probablemente inútil. Unos cuantos traductores respetan el texto original, especialmente si tienen dominio completo de los dos idiomas, como en el caso de Carlos Lozano. Otros, por descuido o por ignorancia, se equivocan hasta el ridículo. Algunos han escrito poemas inspirados en Neruda que si publicaran como obras originales no podrian ni siquiera ser considerados como plagios; tan lejos se hallan del texto español. Que es lo que hace el más conocido de los traductores, Ben Belitt, a pesar de que proclame que ha tomado una actitud de "orante meditativo" ante cada palabra de Neruda.

Grucci tradujo "Apogeo del apio" en 1942. La traducción más conocida es la de Belitt. Para comprender mejor lo que cada uno de los dos traductores hacen en inglés es preciso re-traducir el poema al idioma original: Neruda: ..."son la espuma, la risa"

Grucci: They are the froth, the loughter

(son la espuma, la risa)

Belitt: the spray and the bumors

(el surtidor y los humores) 
Neruda: ... "son los signos del apio".

Grucci: They are the signs of the celery

(son los signos del apio)

Belitt: This, the celery's signature

(Esta, la rúbrica del apio)

Las traducciones de Belitt, (según Evergreen, Dic. 1966, p. 17, es la mano derecha de Neruda en inglés), son descuidadas, retorcidas y pedantescas. Comete errores serios y no comprende que el español nerudiano, con su larga estirpe de cuatrocientos años de uso coloquial, no es el equivalente de la pasajera jerga adolescente de las calles neoyorquinas. Neruda no es dado a los cultismos rimbombantes pero tampoco es callejero. Es raro encontrar localismos en la obra de Netuda, como por ejemplo el caso de biógrafos equivalente a cinemas, pero este intercambio de significado es ambiguo o permutable. Cuando Belitt tecurre al inglés idiomático el resultado es un Neruda grosero y hasta anacrónico. De Belitt, que como poeta es bastante mediocre, dijo Theodore Roethke hace muchos años, que su poesía se inspira más en un acto de la voluntad que en una profunda inspiración personal. Un poeta de estilo retorcido no es el más apropiado para traducir a Neruda. Examinemos "Walking around", poema que ha sido varias veces traducido. Grucci lo tradujo en 1942. Hays lo tradujo en 1946 y Belitt en 1961. Las traducciones primeras son intemporales, se atienen a la clara simplicidad del texto:

Neruda: $\quad$ Sucede que me canso de ser hombre. Sucede que entro en las sastrerías y en los cines marchito, impenetrable, como un cisne de fieltro navegando en un agua de origen y ceniza.

Hays: It so bappens I am tired of being a man. it so bappens, going into tailorshops and movies, I am withered, impervious, like, a swan of felt navigating a water of beginning and asbes.

Grucci: It hapens that I am weary of being a man. It bappens that I enter tailor shops and movies faded, impenetrable, like a swan of felt swimming in spring water and asbes. 
Belitt: $\quad$ Is so bappens l'm tived of just being a man. I go to a movie, drop in at the tailor's -it so happensfeeling wizened and numbed, like a big, wooly swan, awash on an acean of clinkers and causes.

Bellitt: "Sucede que me canso de ser solamente un hombre. Noy a un cine, entro en lo del sastre. - Sucede-/ Sintiéndome arrugado y entorpecido, como un enorme cisne lanudo/ a flote en un océano de escoria y de causas". Lo que en Nenda es desesperación y Taedium vitae, en Belitt es aburrimiento físico. Uno es profundo y el otro superficial. Pero Belitt puede escribir cosas peores. En la tercera estrofa Neruda: "Sucede que me canso de mis pies y mis uñas/ y mi pelo y mi sombra./ Sucede que me canso de ser hombre", Belitt traduce "It so bappens I'm fed-with my feet and my fingernails/ and my bair and my shadow./ Being a man leaves me cold: that's bow it is". La traducción literal parecería decir: "Sucede que estoy barto de mis pies y de las uñas de mis dedos/ y mi pelo y mi sombra. /Eso de ser bombre me deja frio: eso es lo que es". Pero el genuino equivalente en el lenguaje de todos los días de lo que Belitt está diciendo sonaría en español como "Estoy basta la coronilla de mis pies y las uñas de mis dedos. Esto de ser bombre me importa un bledo y ésta es la pura verdad". Cierto que Neruda hubiera podido decirlo así, pero no lo hizo. Tampoco dijo "vulnerable, asombrado con dientes castañeando de sueño" (wide.open and wondering, teeth chattering sleepily) sino que dijo "vacilante, extendido, tiritando de sueño". Que es como lo traduce Hays "vacillating, spread out, shi. vering with sleep". Cuando Neruda escribe aterido Belitt traduce "cold as a stiff" o sea "frío como un difunto" (La explicación de lo que Belitt dice sería "tieso como un cadáver frío", pero así suena más como línea romántica que verso contemporáneo.) las "dentaduras olvidadas en una cafetera" para Belitt están "perdidas" (lost). Los "horribles intestinos" han pasado a ser "un horror de tripas". $Y$ las inolvidables líneas últimas de "Walking around" "calzoncillos, toallas y camisas que lloran lentas lágrimas sucias" y que Hays, Grucci y otros logran transponer a un inglés intenso e iluminado, en Belitt es una línea larga y detallada en que se cambian las prendas de vestir: "Las blusas y toallas y los calzoncillos acabados de lavar/ lentamente goteando una lagrima mugrienta" (the blouses and towels and the drawers nearly washed,/slowly dribbling a slovenly tear). Por cierto que la adición de la ropa de una mujer in. troduce un elemento ajeno al original.

No es mejor en ningún otro poema. "Caballo de los sueños" empieza 
con una palabra clave, Innecesario, el hombre superfluo, inútil, que se analiza y contempla. Para Belitt lo inútil no es el hombre mismo sino el acto de contemplarse ante un espejo, en una interpretación muy superficialmente norteamericana; "innecesariamente, mirándome en los espe. jos..." (Needlessly, watching muy looking-glass image...) El personaje poético es un hombre marginado, vegetativo, el que Belitt construye es un buen hombre aburrido que pasea, perdiendo el tiempo y contemplándose vanamente. En el mismo poema una vaga referencia a una lejana educación religiosa se convierte en personaje de sacristia, así "el dulce catecismo entre cuyas hojas/duermen violetas envejecidas, desvanecidas...) pasa en inglés a ser: los dulces del catequista bajo cuyas bojas/violetas escurridas dormitun $y$ envejecen... (the sweets of the catechist under whose leaves/droined violets drowse and grow old...) $\mathrm{Al}$ parecer ha traducido las hojas del catecismo como hojas de madera, -de puerta o de pupitre-, además de haber convertido el catecismo en catequista. Para evaluar mejor su técnica basta contraponer una estrofa completa, de las más sencillas, de "La gran mesa de piedra dura":

\section{Neruda:}

Nos sentamos juntos a la mesa, a la mesa fría del mundo, y no nos trajo nadie nada, todo se había terminado, se lo habian comido todo

\section{Belitt:}

We take our places at the table together, the world's chilly trenchermen, but no one comes forth with the feast:

the great supper is eaten and the guests left no crumbs on the stones.

(Nos sentamos juntos a la mesa, los mas grandes tragones del mundo, pero nadie vino a servirnos el banquete,/lo babian comido todo/y los invitados no dejaron ni migajas sobre las piedras). Y la más clara prueba de que este hombre no entiende para nada la poesía de Neruda, está en "Nacimiento" en que Neruda está hablando de sí mismo, del hombre nacido en Parral en el mes de julio, en el invierno de Sur América: 


\section{Parral se llama el sitio \\ del que nació \\ en invierno}

$\mathrm{Y}$ que convierte en "Parral es el nombre/para/lo que trajo el inviemo" (Parral is the name/for/what winter brought forth). No basta decit que la traducción es inadmisible, sino que es también de muy mal gusto.

Pero basta de Belitt. Con él, en $A$ New Decade, colabora Alistair Reid, poeta inglés de fama respetable $e$ invariable buen gusto, pero sus descuidos e ignorancia en este libro son tan imperdonables como los de Belitt. En "Caballos" cambia las imágenes a capricho, el original "Y desde mi ventana un solitario circo / mordido por los dientes del invienno" se convierte en inglés en "Desde mi ventana podia ver una palestra desierta/un circula mordido por los dientes del invierno" (From my window, I could see a deserted arena, a circle bitten out by the teeth of winter) como si estuviera adivinando palabras en lugar de interpretarlas. También convierte niebla en nieve (snow).

A Reid también le da por interpretar las metáforas. "De crines parecidas al sueño de la sal", nos da "de crines que recuerdan un sueño de pura gracia" (their manes recalling a dream of pure grace). En "Partenogénesis" el "Por suerte no les hice caso" resulta ser "Por suerte no les importó" (Luckily the did no mind). El "si continuar aconsejado" es "continuar aconsejándolos" (to continue to give them comsel) que además de ser una línea de construcción atrabiliaria, quiere decir lo contrario del original. El "abuelo" del "Regreso a una ciudad" es, para Reid, una "abuela" (grandmother). En "Por boca cerrada no entran moscas", el dístico precioso. "Por que se enfría la esmeralda/como una ahogada submarina" produce "como un submarino ahogado" (like a drowned submarine) y aunque haya que conceder que se trata de un verso difícil, no se puede olvidar que seis estrofas mås abajo convierte la madreselva en jungle, o sea, selva, jungla; la madreselva, Lonicera implexa, es una planta muy común que se llama en inglés boneysuckle. Una de las mayores meteduras de pata de Reid está en el primer verso de "Sumario": "Estoy contento con tantos deberes" que trasmuta en "Estoy contento con las montañosas deudas", o peor: "Estoy contento con las montañas de deudas". (I am happy with the mountainous debts...) Neruda está hablando de deberes, de responsabilidades, de funciones, de obligaciones, pero no de deudas porque la palabra (debts) no se escapa en inglés de la implicación de ser una obligación financiera.

Alistair Reid ha publicado también $W e$ are many, una preciosa edi- 
ción para la cual Neruda mismo escogió los poemas. Las traducciones son finas, acertadas, elegantes. Solamente hay en el libro algunas erratas en el texto español, pero las versiones inglesas son encantadoras.

Nathaniel Tarn es otro de los escritores ingleses que se han dedicado a trabajar sobre Neruda. Ahora está enseñando literatura comparada en la Universidad de Rutgers, en EEUU. Su primer Neruda es la traducción de las Alturas de Maccbu Piccbu. Es muy buena si se compara con la de Belitt, que publicó parte de las Alturas en su selección de 1961. Por ejemplo el conocido "o vastas construcciones de viento y ventisquero" que Belitt traduce a un prosaico "enormous constructions of ice and the wind" en 'Tarn es "or vast structures of wind and snowdrift", mucho más apropiado. La traducción de Tarn es de 1966, pero la de Flores, que data de 1944, es superior. Tarn evita traducir "en lo más genital de lo terrestre" y lo que Angel Flores había dicho en elegante exactitud into the most terrestrial genital se convierte en the most serret organs of the earth. Cuando Neruda escribe "mesa", Flores dice naturalmente table, pero Tarn corrige al poeta y traduce floor, en la vieja idea de que los críticos - sobre todo si son catedráticos universitarios-, saben más que los poetas. Los verbos españoles desafían la comprensión de los angloparlantes. En el canto II los imperativos mátala y agonizala, sumérgela se trastocan en presente, tercera persona, singular. Cuando Neruda escribe Madre de piedra, espuma de los cóndores, Tarn traduce espuma por esperma y el verso resultante es sonoro, nuevo, original pero la espuma de Neruda no sugiere que Macchu Picchu es la hija de los cóndores y ni siquiera una envuelta interpretación freudiana podría justificar esta transposición, después de todo Neruda hubiera usado la palabra esperma si es esa la que hubiera querido. Algunas de estas traducciones parecen partir de la teoría de que no hay en español palabras suficientes para expresar ciettas ideas y por lo tanto se procede a refinar el lenguaje de nuestros poetas, como si se estuviera traduciendo de un idioma primitivo a uno más desarrollado.

Tarn presenta también ciertas inclinaciones cardenalicias. Como España es el país más católico de Europa, trata de trasvasar esta vivencia religiosa a culturas que nada tienen de cristianas. El verso "la ciudad como un vaso se levantó en las manos" se transforma en inglés en ofrenda religiosa, con ribetes de misa solemne puesto que el vaso se ha convertido en cáliz y la implicación de esta imagen es profundamente antinerudiana; no hay cálices en la imponente y desolada realidad de Macchu Picchu. "La más alta vasija que contuvo el silencio", refleja la piedra de la fortaleza, la tierra, el barro, no es un crisol, (crucible) 
como lo traduce Tarn; no tiene que ser purificada, es pura, exacta. Tampoco se comprende por qué la "serpiente despeñada" que casi suena a Góngora, se ha de convertir en coiling lucifer. En inglés Lucifer es Venus matutina; o es acaso una referencia al Viejo Testamento, o acaso el monstruo que Dante describe en el Infierno. Pero nada hay en Macchu Picchu de mitologías cristianas, "Juan Cortapiedras, hijo de Wiracocha" escribió Neruda, y Wiracocha, con su tiara de sol, con el trueno en las manos, es el dios que llora. No es una imagen cristiana.

La traducción de Tarn es elegante, atildada, pero trae pasajes inaceptables, descuidados: "dime si fue su sueño/ronco, entreabierto, como un hoyo negro" no se puede traducir por "dime si roncaba, con la boca abierta como una negra cicatriz". (wether be snored,/his moush agape like a dark scar).

Otro de los más conocidos traductores de Neruda es W. S. Merwin, un poeta norteamericano que ha escrito muy buenos versos, como "White Goat, White Ram" y "December: Of Aphrodite". Pero aunque Merwin ha logrado algunas líneas iluminadas la mayor parte de su Neruda es desdichado, no porque le falte instinto poético sino por la pobreza de su vocabulario. Se encargó de publicar los versos amorosos, los Veinte poemas y la canción desesperada, que pierden en sus manos todo su sabor de ofrenda delicada. Si Merwin dice en inglés Speecbless, my friend en la traducción literal de "muda, mi amiga", el resultado es dos ideas muy distintas. Este verso es del poema II, en el cual también Merwin confunde sujetos y verbos y predicados. En el poema III Merwin escoge el más inaplicable de los significados del verbo doblar:

Neruda: Ah tu voz misteriosa que el amor tiñe y dobla... doblarse las espigas en la boca del viento.

Merwin: Ab your misherious voice that love tolls and darkens... (Ah tu voz misteriosa que el amor toca (a muerto) y oscurece. . the ears of wheat tolling in the mouth of the wind las espigas tocando (a muerto) en la boca del viento.

Es obvio que confundió teñir con tañer y que se le han escapado los otros sinónimos de doblar, someter, inclinar, duplicar, arquear, con los que Neruda ha jugado en esa estrofa. En el poema V, "Pero se va tiñendo con tu amor mis palabras" traduce tiñendo, del verbo teñir, 
por ringing (sonando, resonando) es decir lo confunde otra vez con tañer. Aunque parezca increíble, en el poema VI, "en que mi ser ardia" se convierte en in which my thirst was burning con lo que muestra haber confundido ser con sed. En el poema VII "tus ojos ausentes/que olean como el mar..." traduce olear, de ola, como si fuese verbo oler y escribe "your absent eyes/that smell like the sea..." En el poema XII "Acogedora" es You gather things to you (Recoges cosas). Casi todos los tiempos de verbo están mal traducidos y es redundante citar ejemplos. Pero hay dos etrores que no se pueden pasar por alto. En la "Canción desesperada" cuando Neruda dice "De tumbo en tumbo" la versión inglesa dice From tomb to tomb (de tumba en tumba). Y en el poema $\mathrm{XX}$ la famosa línea entre comillas "La noche está estrellada", en inglés no solamente no tiene estrellas sino que está rota en mil pedazos: The night is shattered.

Jerome Rothenberg es otro de los traductores profesionales; su traducción del "Poema número diez" se puede comparar con la de Merwin. El verso la fiesta del poniente en los cerros lejanos se le escapó tanto al uno como al otro. Merwin se decidió por usar la misma palabra en inglés, fiesta, tomada del español y que tiene por lo tanto connotación de inglés norteamericano que sugiere la vecindad de México. Rothenberg la tradujo por feasting que es aún peor porque conlleva la idea de banquete más que de fiesta. Y esto a pesar de ser una palabra derivada del latín festivus que tiene muchos sinónimos en inglés. Merwin sabe conjugar los verbos un poco mejor, aunque como todos los traductores de Neruda sea completamente derrotado por sus pocos subjunti. vos. Rothenberg no sabe nada de verbos y planta todos los tiempos en el presente. La sintaxis del español también se le escapa, el Yo te recor. daba con el alma apretada/de esa tristeza que tú me conoces pasa al inglés como T'e recuerdo con tu alma encerradaf en la oscuridad de conocerne (I remember you with your soul shut tight/in the darkness of knowing me).

Otro de los traductores jóvenes es Clayton Eshleman. Es buen poeta pero como traductor es también de los que trata de re-crear, aunque nunca llegue a los ofensivos extremos de Belitt. Si Neruda dice aguas azules para una batalla, Eshleman traduce "aguas azules esperando una tormenta (blue waters waiting for a storm.) Cierto que Eshleman tiene sentido del poeta y dominio del inglés poético, pero su dominio del español es de adivinación e improvisado. La línea cieno la confunde con sienma (siena) y la traduce como pigmento (pigments). Donde Neruda dice "Me refiero", Eshleman traduce "Miro" ( $I$ look at). Como 
hace una traducción de palabra por palabra, las valoraciones de la sin. taxis española se le escapan y donde Neruda piensa en una sala por donde pasa un río, Eshleman ve un río que pasa por una sala. Por eso también confunde el verbo viajar, viajo por viejo y el extraño y tan nerudiano porque estoy triste y viajo pasa al inglés como "porque estoy triste y viejo" (because I am sad and old) (Ejemplos tomados de "Melancolia en la familia").

Después de examinar las variadas formas que toma en inglés el interés en Neruda, se pueden observar ciertas características salientes. Lo más importante es reconocer que aunque en el ambiente universitario no se estudia tanto a Neruda como a otros escritores de la América española, el público, en cambio, lo ha leido con mayor constancia y durante más tiempo. Las traducciones de Neruda han estado en circulación por más de dos décadas - sin el recursos de subvenciones-, pero no por eso han cesado las reimpresiones o los experimentos para producir mejores textos.

Los escritores de habla inglesa que han tenido la suerte de ponerse en contacto con Neruda y con la poesía contemporánea en español son sus amigos y devotos. $Y$ los poetas mayores le han dedicado conmovedores tributos, como hizo William Carlos Williams que le dedicó un poema después de haber leído sus odas. Este poema se publicó en Rutgers Review (Spring, 1967, p. 25). Según nota del editor, Pedro Amaral, William Carlos Williams pidió que el poema le fuera enviado a Neruda. Como esto no se hizo Pedro Amaral lo publicó en la revista estudiantil -después de la muerte de Williams - con la esperanza de que algún día llegara a las manos de Neruda. Pero las revistas estudiantiles tienen poca circulación y Neruda nunca debe haberlo leído ya que no aparece en la bibliografía de Loyola. Como se trata del más puro y sentido tributo que se ha hecho a Neruda en inglés, lo traducimos a continuación. Se titula "Homenaje a Neruda, el poeta coleccionista de conchas":

Ahora que estoy casi ciego, /no importa cómo haya sucedido/ porque puedo ver tan bien como/ todo el mundo. Mi imaginación// se ha vuelto a mirar hacia adentro/ como le pasó a mi madre cuan. do/envejeció. Sus sueños tomaron el lugar/ de su mirada. Su lengua//materna era el español, el cual/ naturalmente, nunca/se le olvidó. Era también/ el idioma de Neruda el// poeta chileno que coleccionaba/ conchas marinas en/ las playas de su tierra, hasta que/se llegó a decir que tenía//la segunda colección del/mundo. Ten paciencia/con él, madre, la/invariable belleza de// las con- 
chas, como el/mar mismo, dio/a sus líneas el variable tono/que requiere el verso moderno.

(Tribute to Neruda the poet collector of seashells. Now that I am all but blind,/ however it came about,/ though I can see as well/as anyone - the imagination//has turned inward as happened/ to my mother when she/became old: dreams took the/place of sight. Her native// tongue was Spanish which,/of course, she/never forgot. It was the/ language also of Neruda the//Chilean poeta - who collected/ seashells on his/native beaches, until he/ had by reputation, the second//largest collection in the/world. Be patient with/him, darling mother, the/ changeless beauty of //seashells, like the/sea itself, gave/his lines the variable pitch/ which modern verse requires.)

Hubo, para los lectores del mundo de habla inglesa, una introducción profética a Neruda, la de Concha Meléndez que llamó a Neruda joven "genio esquivo". Luego el momento culminante en que un crítico de respeto -Donald Hall - une su nombre al de Whitman como los dos grandes poetas de América. $Y$ en el centro este homenaje sincero y delicado, de uno de los mejores poetas que los Estados Unidos han producido en el siglo presente.

\section{Anotaciones Complementarias.}

Hispania, la revista de la Asociación de profesores de español y portugués, reseña en el volumen 55, mayo de 1972, p. 357, un homenaje en honor a Neruda celebrado en la Universidad de Boston el 26 de enero del presente año (1972). Hablaron Juan Cano, Carlos Hamilton y Emir Rodríguez Monegal. En la página 369 del mismo número Robert G. Mead reproduce una nota que firmada por John Felstiner se publicó en The New Reprublic, 25 de diciembre, 1971, p. 29. Felstiner se pregunta por qué Neruda es todavía desconocido en los EEUU y contesta que su espíritu inspirador, Walt Whitman, todavía no ha sido asimilado en el país.

New York Times. Una vez uno de los poetas más anti-organización de los EEUU, Karl Shapiro, dijo en:To Abolish Cbildren and other Essays (Chicago, 1968, p. 237) que Neruda es "un gaucho del comunismo". Shapiro admira a Neruda pero sus contrapartes en el poder 
periodístico o universitario todavía andan a la caza despiadada de Neruda. El New York Times continúa en el mismo estilo reservado de gran dama desdeñosa. Por razones más relacionadas con la política que con la literatura el NYT, bajo la apariencia de imparcialidad, no logra ocultar del todo su antipatía por el poeta chileno a la que sustituye con constantes referencias a Borges, aunque en la práctica las actitudes políticas de Neruda se acercan más a la posición editorial del Times que las posturas de Borges. El caso es que el premio Nobel parece haber agudizado los ataques a soslayo del NYT.

El 30 de abril de 1972 en la p. 47 del NYTBR, John Leonard, en la reservada manera crítica que podríamos describir como ultradignificado puritanismo presenta a Neruda como un muñeco de trapo que anda haciendo el ridículo sin saberio: "Su discurso trató metafóricamente de convertir a Chile en un albatros y a los Estados Unidos en un arquero asesino que trata de obligar a Chile a pagar una deuda extranjera de tres billones de dólares. Recibió una gran ovación". Es un comentario muy mono, que no resiste ni el análisis estadístico o económico - por lo de los tres billones- o el literario. Lo del albatros es más rococó neoyorquino que nerudiano.

El 28 de mayo, en la página 27, el NYTBR publicó, en la misma columna, una especie de contestación firmada por Richard Locke. Vuelta a las referencias a "Yeats, Eliot, Lawrence, Pound o Pablo Neruda". Realmente todo el estruendo acerca de política y literatura formaba parte de una campaña anti.Ezra Pound que cuajó en la extraordinaria afirmación de que Pound no podía recibir la medalla Emerson-Thoreau por razones de moralidad. Por razones opuestas, pero igualmente ciegas, se ataca lo mismo a Pound que a Neruda.

El NYT había dado amplia publicidad a las declaraciones de Neruda en el mes de abril, durante una corta visita a Nueva York. El 16 de abril de 1972, p. 10, Henry Raymont transcribe el comentario de Neruda sobre los problemas de Solzhenitsyn a quien el gobierno soviético no dejó ir a Estocolmo a recibir el premio Nobel en 1970. Neruda dijo que no quería tomar parte en discusiones personales ni ser instrumento de propaganda antisoviética. "Después de todo - añadió- hay más novelistas perseguidos en los países capitalistas que en los países socialistas". Ante la insistencia de los reporteros añadió que estaba aburrido de discutir el tema. $\mathrm{La}_{\mathrm{a}}$ ingenuidad local en cuanto a persecuciones de intelectuales en los países capitalistas se muestra en una carta firmada por Julius Epstein, publicada por el Times unos días después. Epstein pide que se repudie a Neruda enfáticamente y se refiere a los "conflictos 
triviales que algunos escritores puedan tener en los países capitalistas" Neruda no habría de llamarle trivial al exilio, el hambre o la cárcel, temas que los intelectuales de nuestra América conocen a fondo. En cuanto a la represión de la inteligencia, los rusos no son únicos.

Por otra parte el NYT publicó una balanceada reseña de John Coleman sobre Selected Poems, la traducción recopilada por Tarn, y Neruda y Vallejo de Bly, con Knoepfle y Wright. (NYTBR, May. 7, 72, p. 4) London Times.-La crítica inglesa se mantiene más receptiva pero no logra evitar el consabido comentario étnico. Peter Porter (TLS, May. 12, 72) afirma que "Inglaterra no tiene un escritor de influencia internacional, un nombre que actúe como conjuro en las reuniones, alguien que atraiga al público, como Mailer, Grass o Beckett. El único poeta que parece poseer tal don es Pablo Neruda. Pero muchos de nuestros más entusiastas admiradores de la poesía suramericana logran mostrar, en la más ligera conversación, que ni saben español ni pueden razonar." La frustración celosa es evidente.

Más cómodo y más ilustrativo es examinar la influencia de Neruda en los escritores contemporáneo. El New York Times, el 7 de mayo de 1972 publicó un poema de Yevgeny Yevtushenko titulado "¿Quién eres tú, Gran Cañón?" La huella de Neruda es inescapable, es la versión rusa de "Que despierte el leñador" con un ligero toque de las Alturas de Maccbu Picchu:

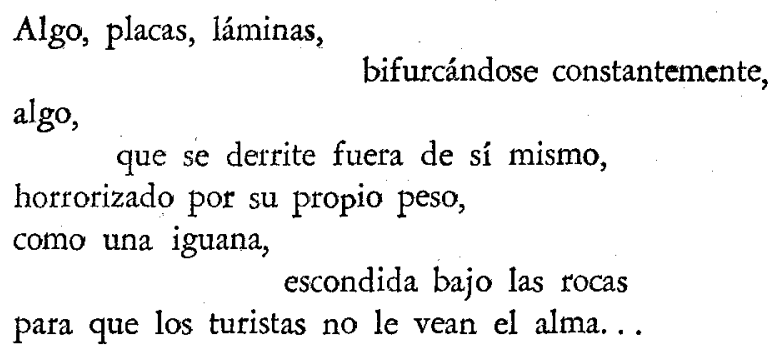

En el poema de Neruda "Hay unas altas piedras rojas, el aire/ salvaje de mil manos/ las hizo edificadas estructuras:/ el escarlata ciego subió desde el abismo..." Y en el ruso: "Sandwiches rocosos de témpanos rojos/ toda la sangre de los asesinados/gota a gota/ comprimida como semillas de girasol. .." No faltan las nuevas alusiones políticas. Sputnick. El Ché. En fin, un Canto del leñador puesto al día, y traducido al inglés por Albert C. Todd, un profesor de Queens College.

La poesía en inglés, contemporánea, es, a veces, anécdota directa, tanto que a veces sólo se separa de Campoamor por la ausencia de la 
rima. Pero tiene un encanto fresco, limpio de retórica, audaz en los vocablos. Uno de sus mejores practicantes es Tom Wayman que en el último número de New American Review publicó un poema titulado "Influencias". Es un gesto de protesta, un zafarse de la ominosa presencia del primer poeta moderno de cualquier idioma. Wayman dice:

Me siento aquí, frente a mi escritorio

-y se convierte en Pablo Neruda!

Su rostro macizo me observa pensativo

asomado entre mis lápices.

Le digo: por favor. Tengo que empezar a escribir.

Tengo que ser Wayman, seguir con mi trabajo.

Déjame en paz. Vamos! Y él se va.

La descripción continúa. Neruda se va y regresa. Le señala la frase que debe cambiar $y$ al fin termina Wayman:

Entonces trato de ser vivo.

Le digo que me voy pero que regreso en seguida.

$\mathrm{Y}$ me marcho, cuidadosamente dejándolo encerrado

dentro del cuarto.

Afuera, en el portal al aire fresco,

se ven las montañas de la costa norte, detrás de la ciudad.

Ahora estoy solo, y tiemblo.

Nada se oye en los patios vecinos

solamente el tráfico

y una silenciosa risilla chilena.

Y qué bueno cerrar un trabajo sobre Neruda con las palabras de un poeta y poder escuchar todo lo que hay de sardónico y paciente en sus inesperados silencios.

Esperanza Figueroa

Elmira Collegc 
